\title{
Conjugate Additions of Sulfur-stabilized Anions to Unsaturated Lactams. Synthesis of Polyfunctionalized benzo[a]quinolizinone
}

systems

Eva Garcia, Esther Lete, * and Nuria Sotomayor

Departamento de Química Orgánica II, Facultad de Ciencia y Tecnología, Universidad del País Vasco / Euskal Herriko Unibertsitatea.

Apdo. 644. 48080 Bilbao (Spain) esther.lete@ehu.es

\section{Supporting Information}

Contents of file 2(current file)

- Copies of ${ }^{1} \mathrm{H}$ NMR and ${ }^{13} \mathrm{C}$ NMR of compounds 

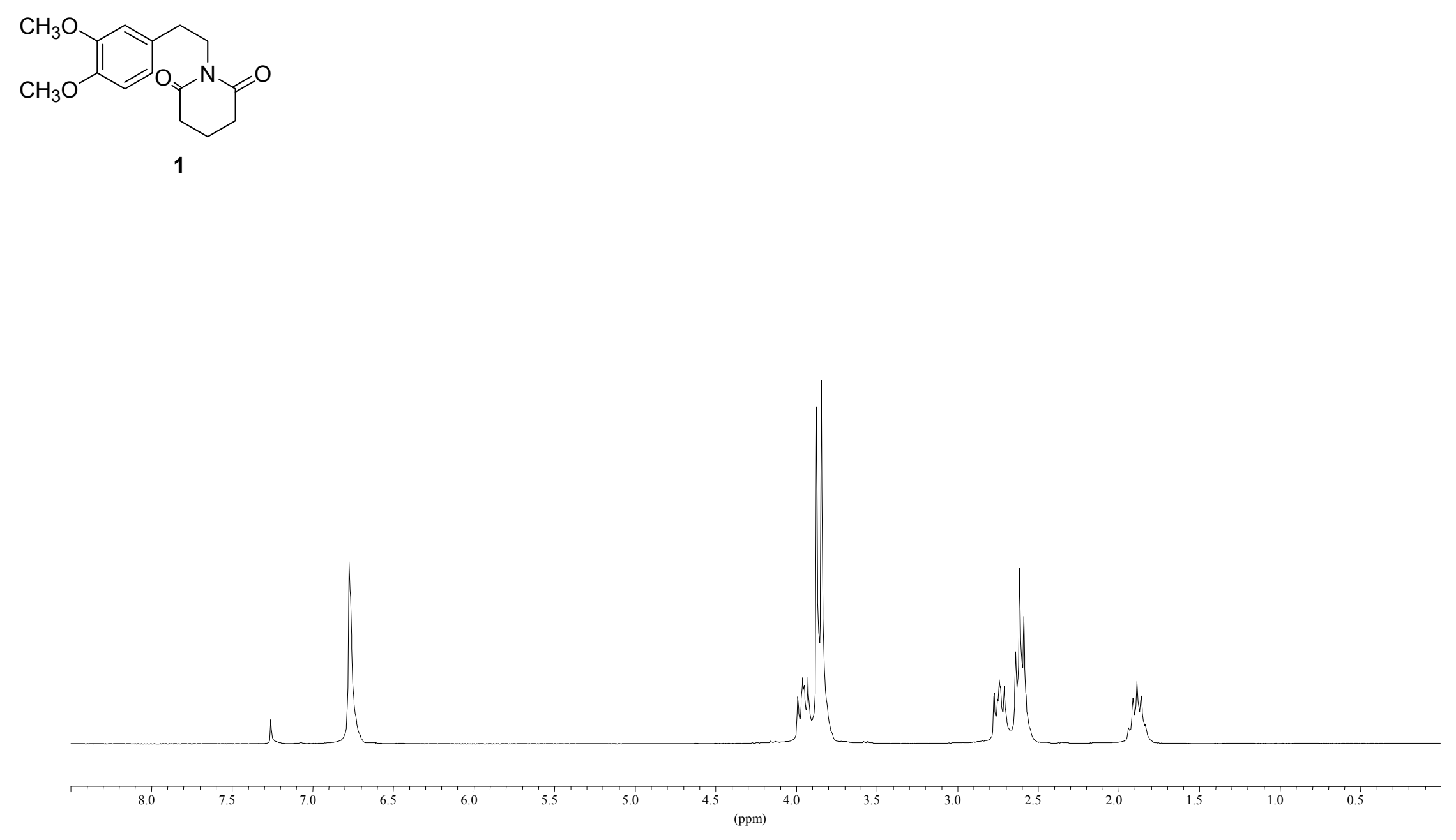


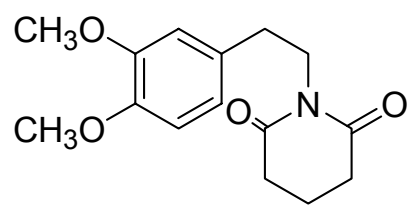

1

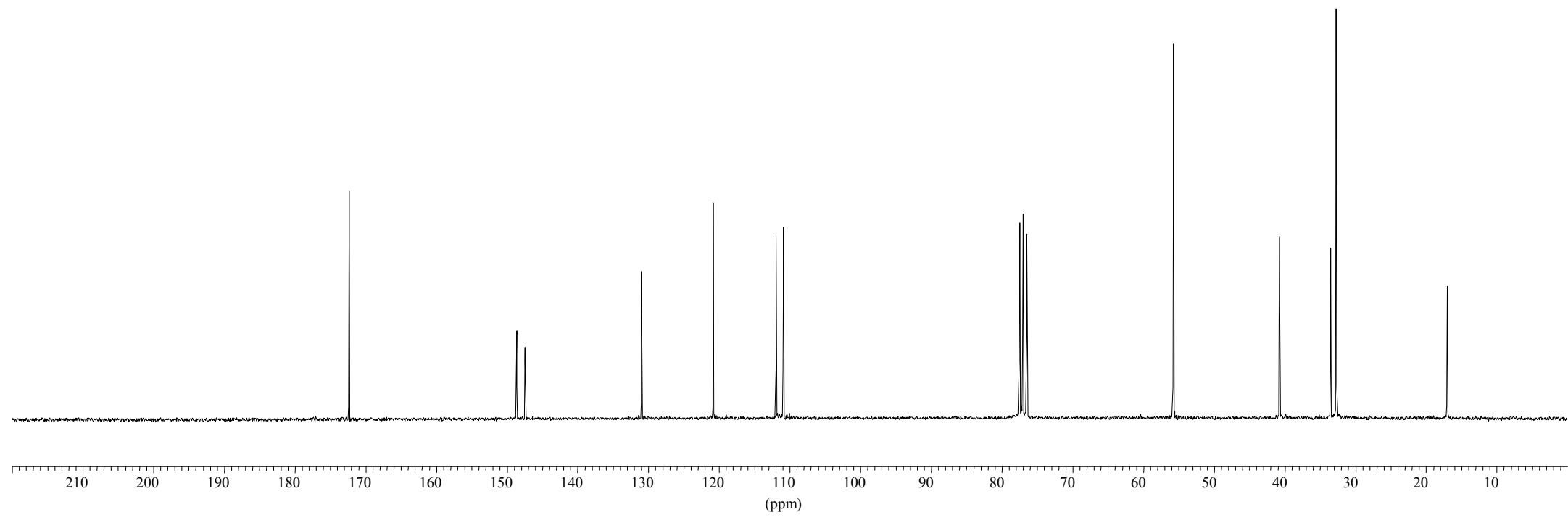

S-11 

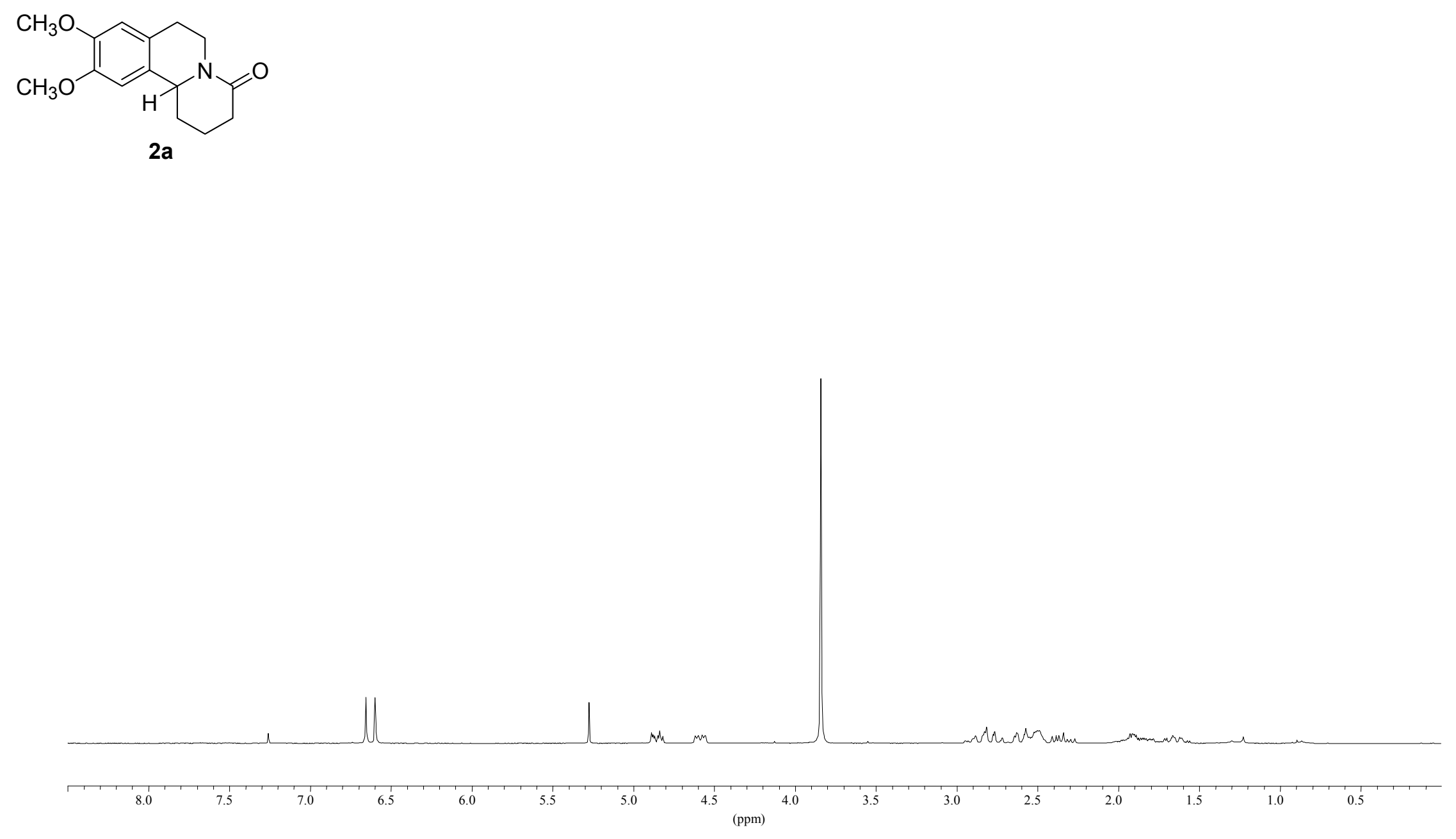

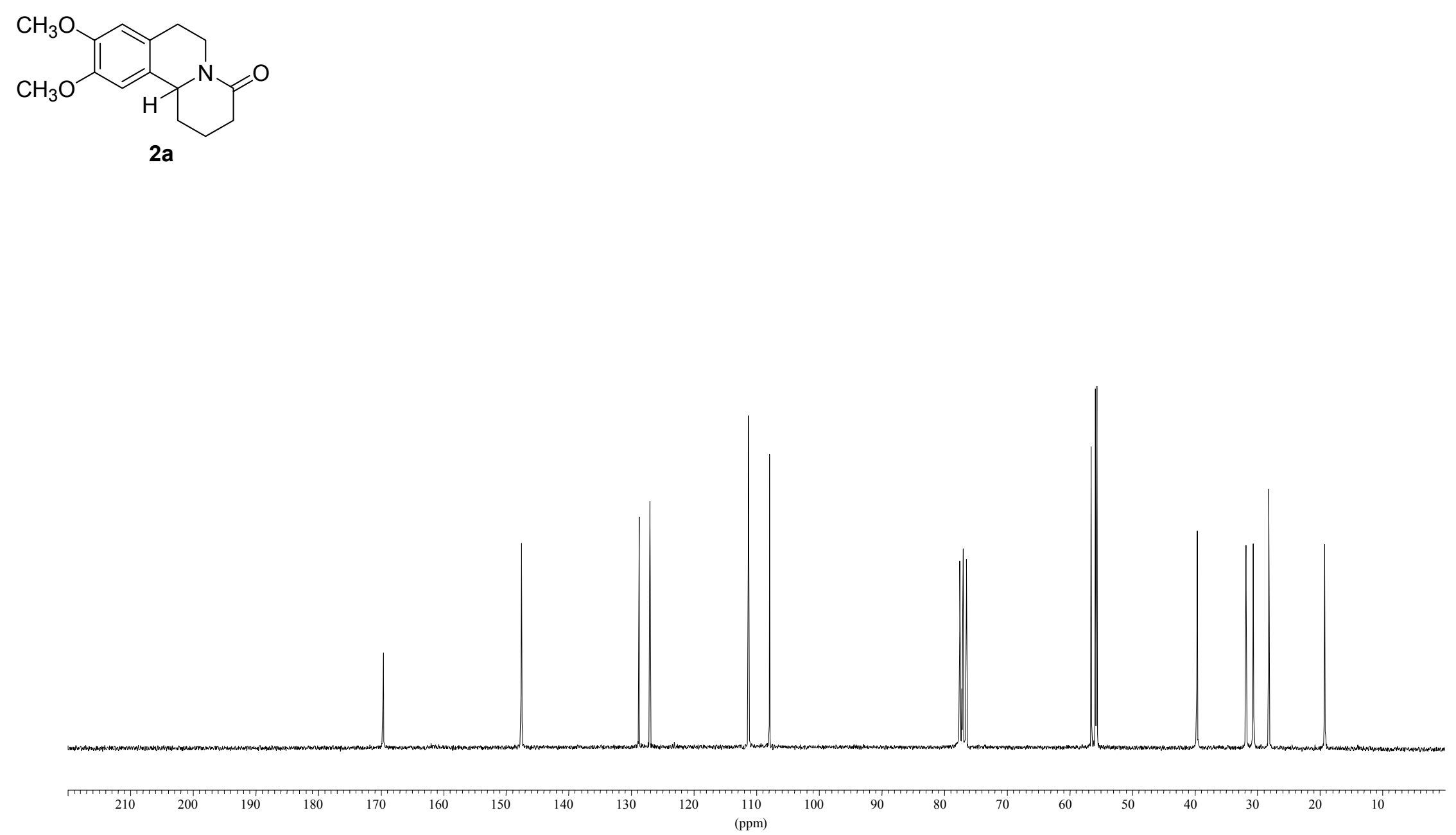


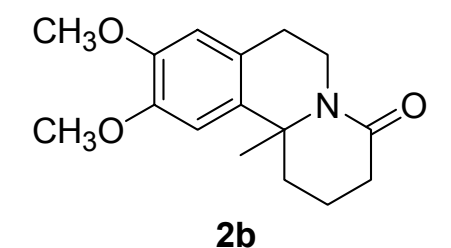

2b

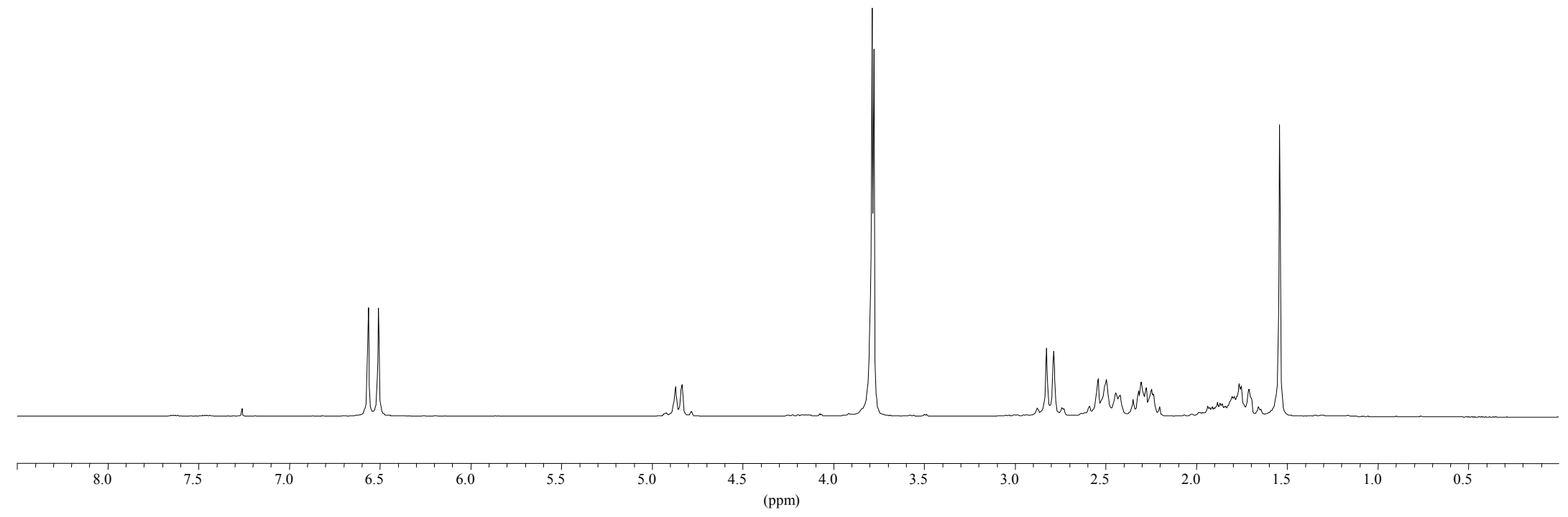




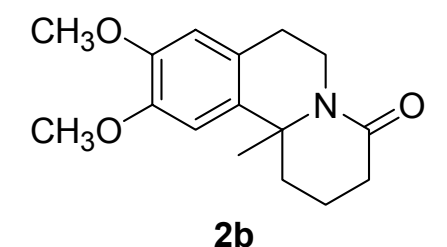

2b

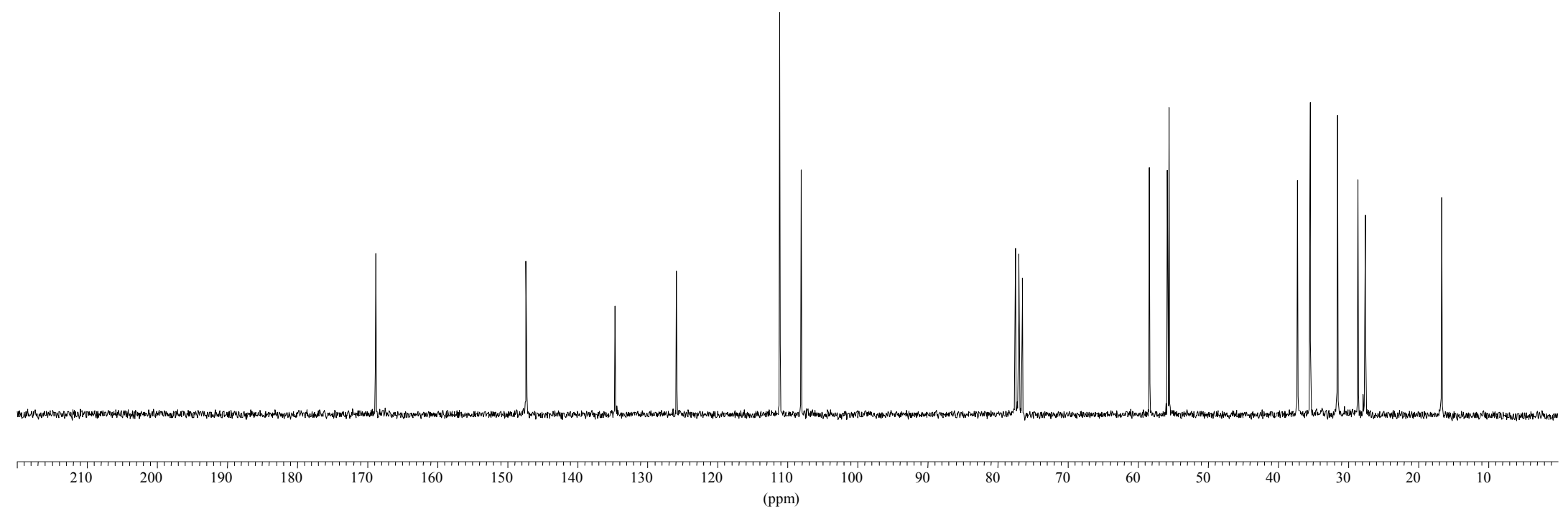




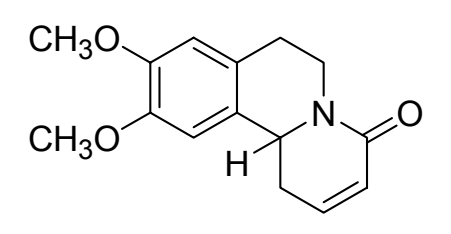

$3 a$

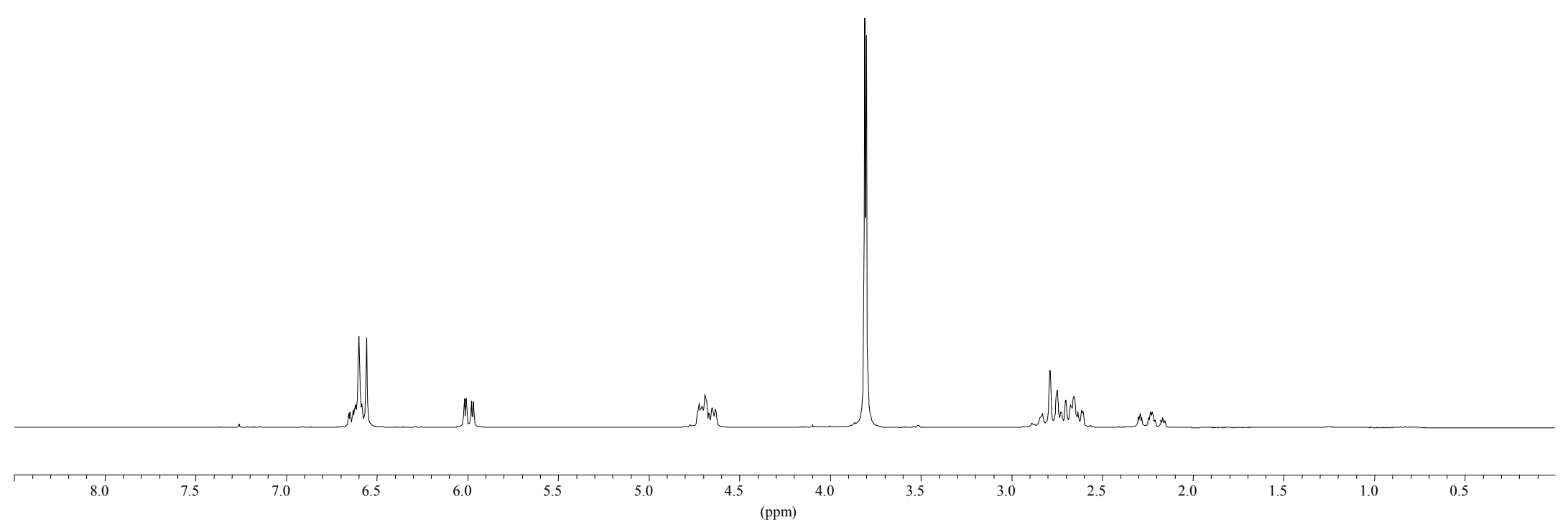




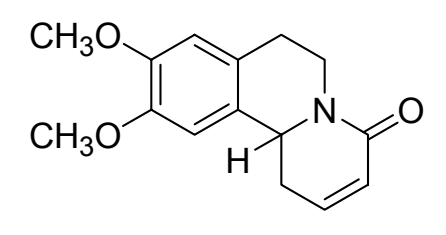

$3 a$

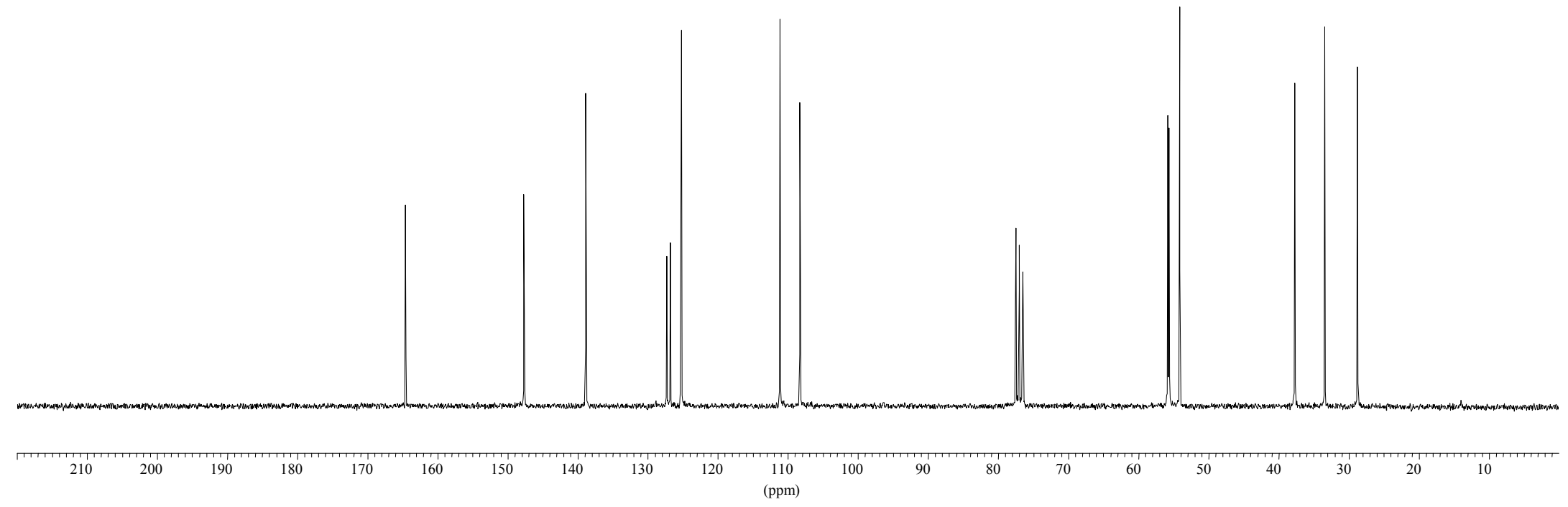




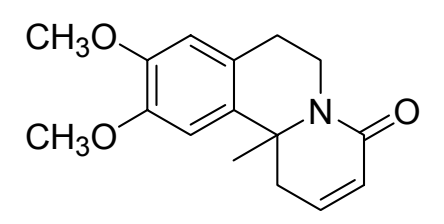

$3 b$

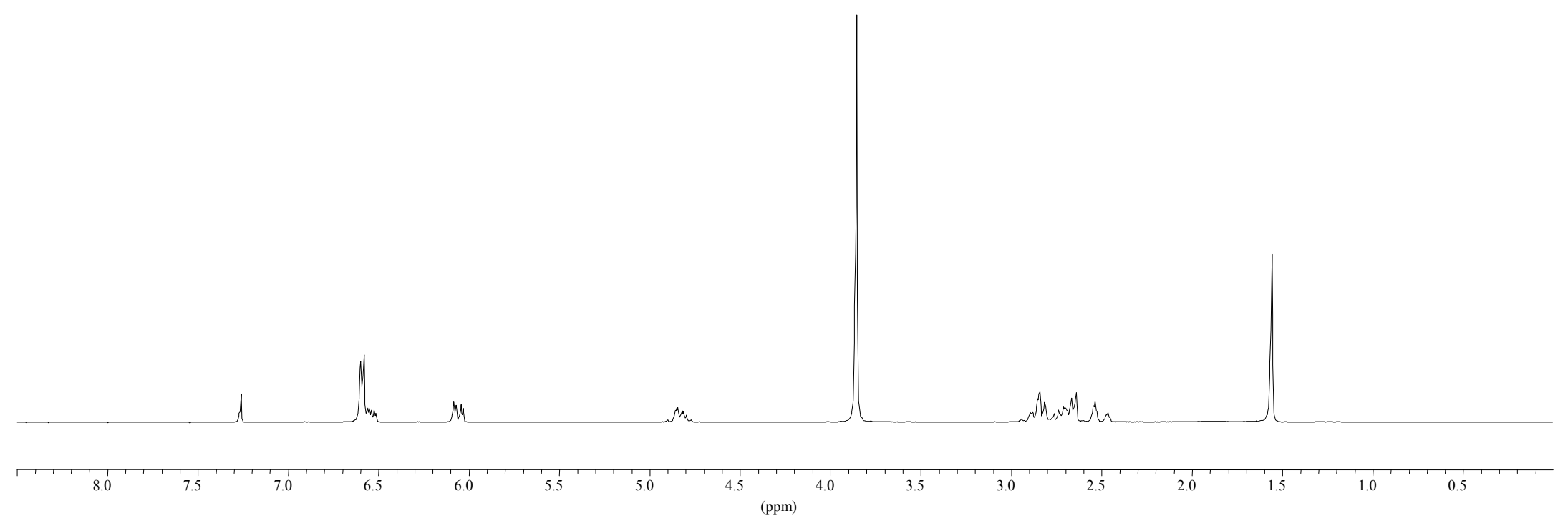




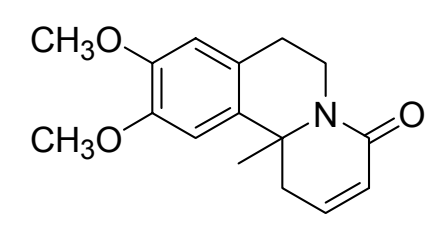

$3 b$

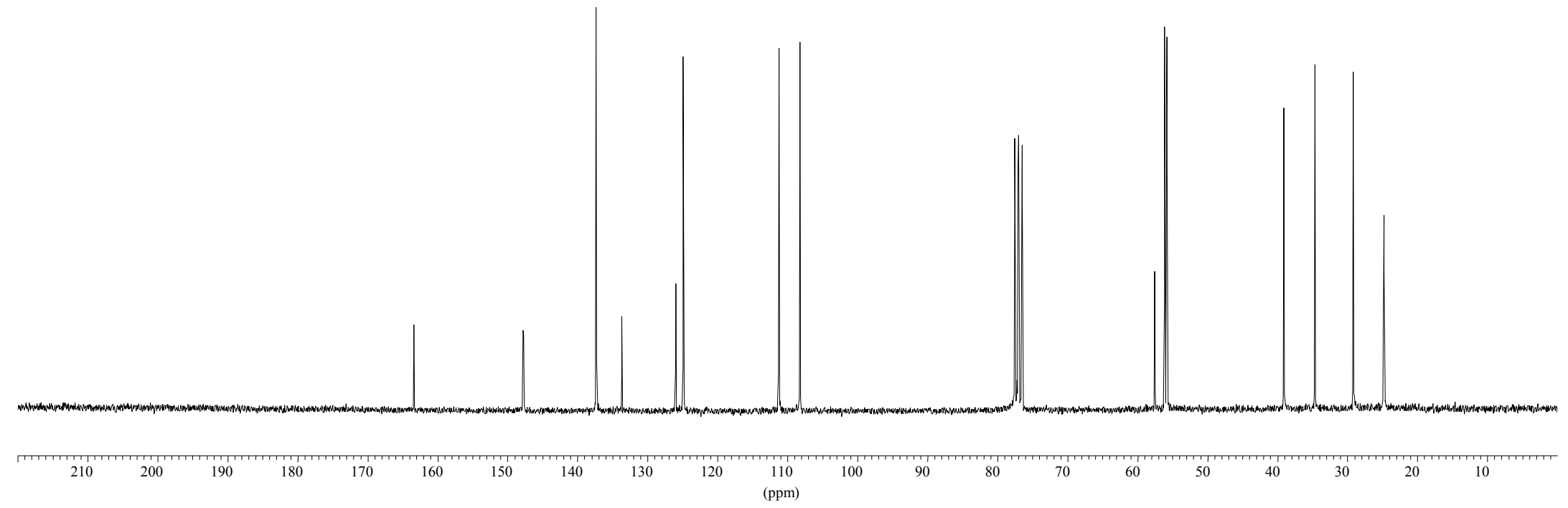




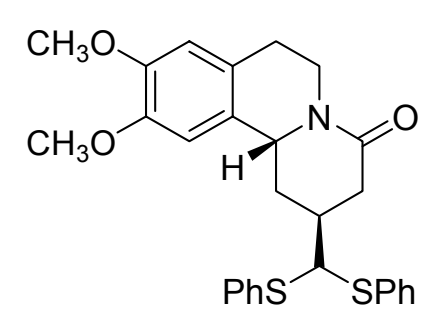

$5 a$

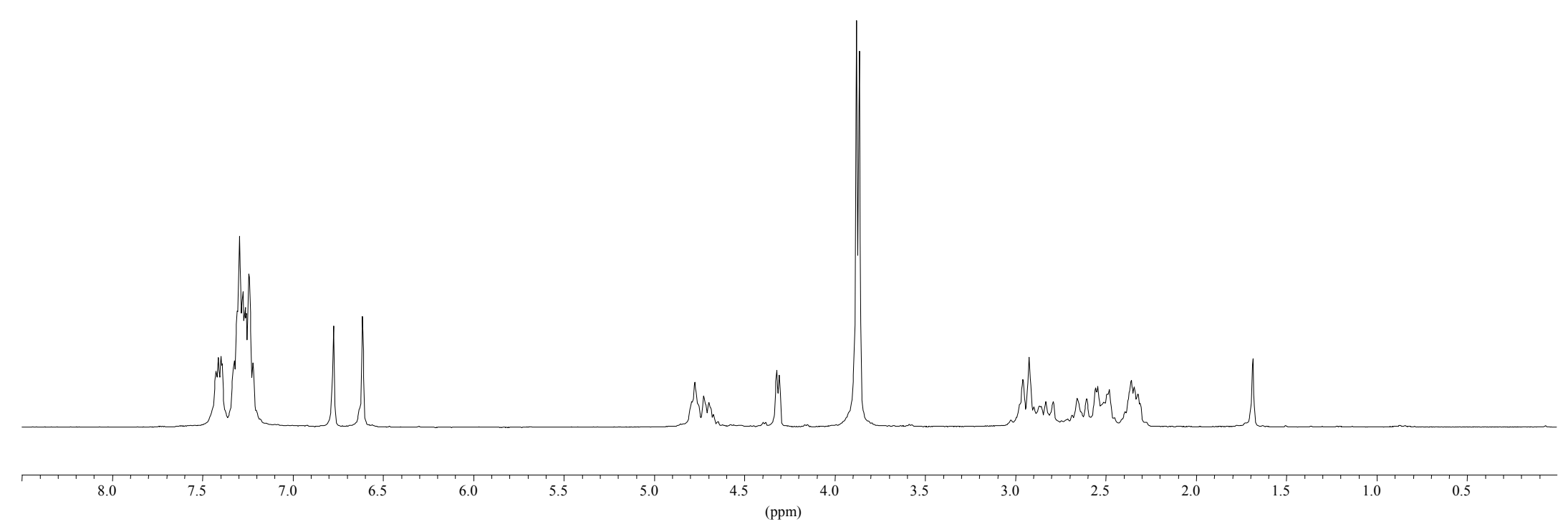




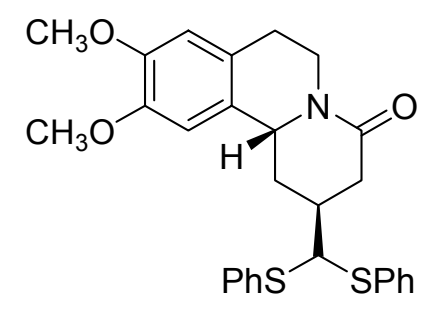

$5 a$

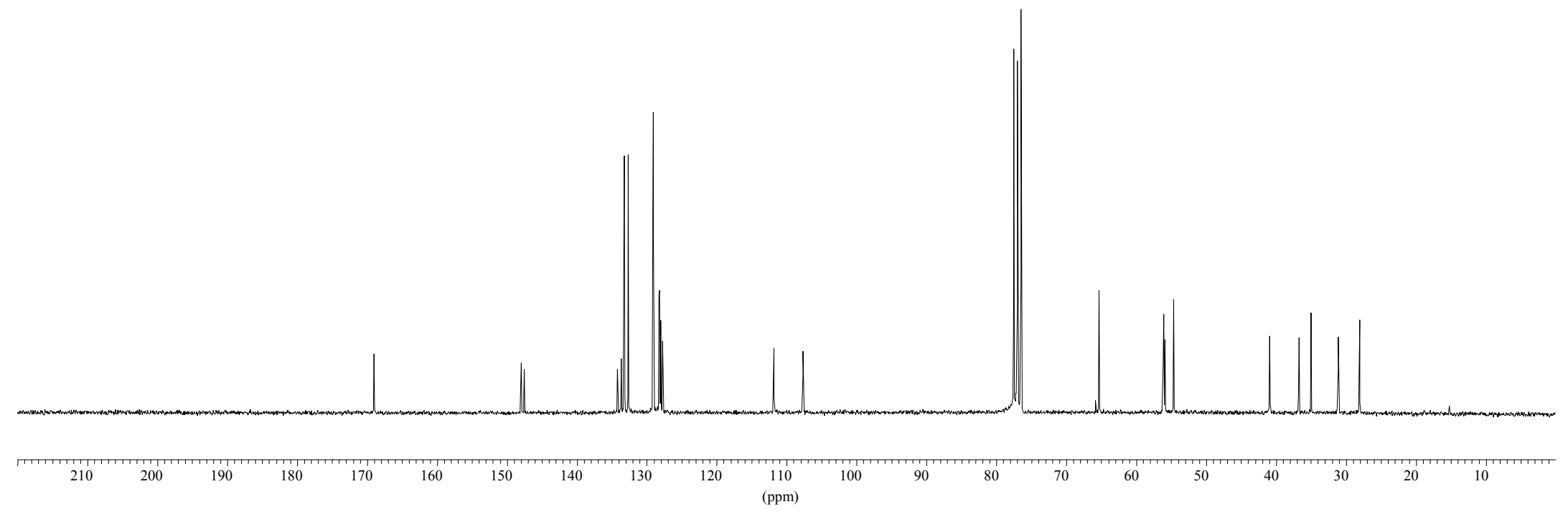




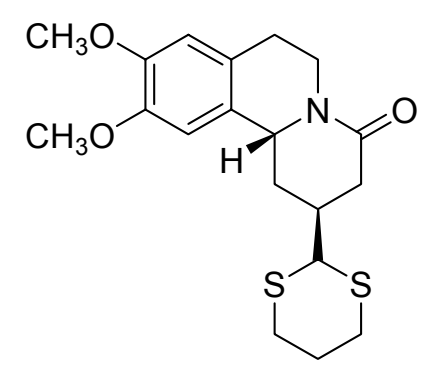

$5 b$

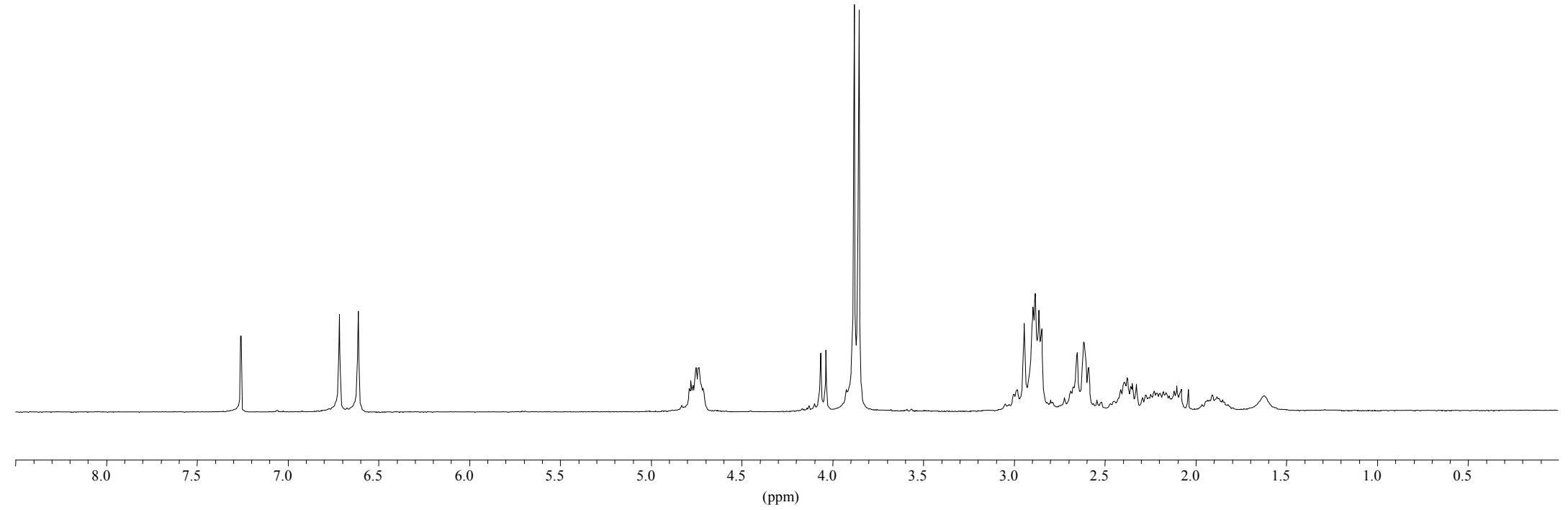




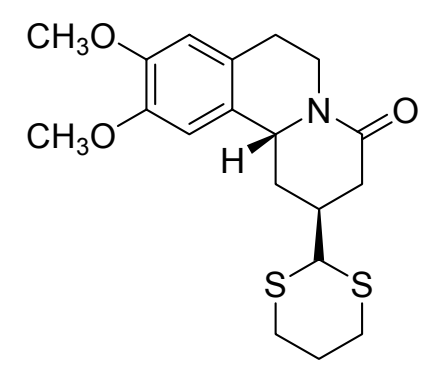

$5 b$

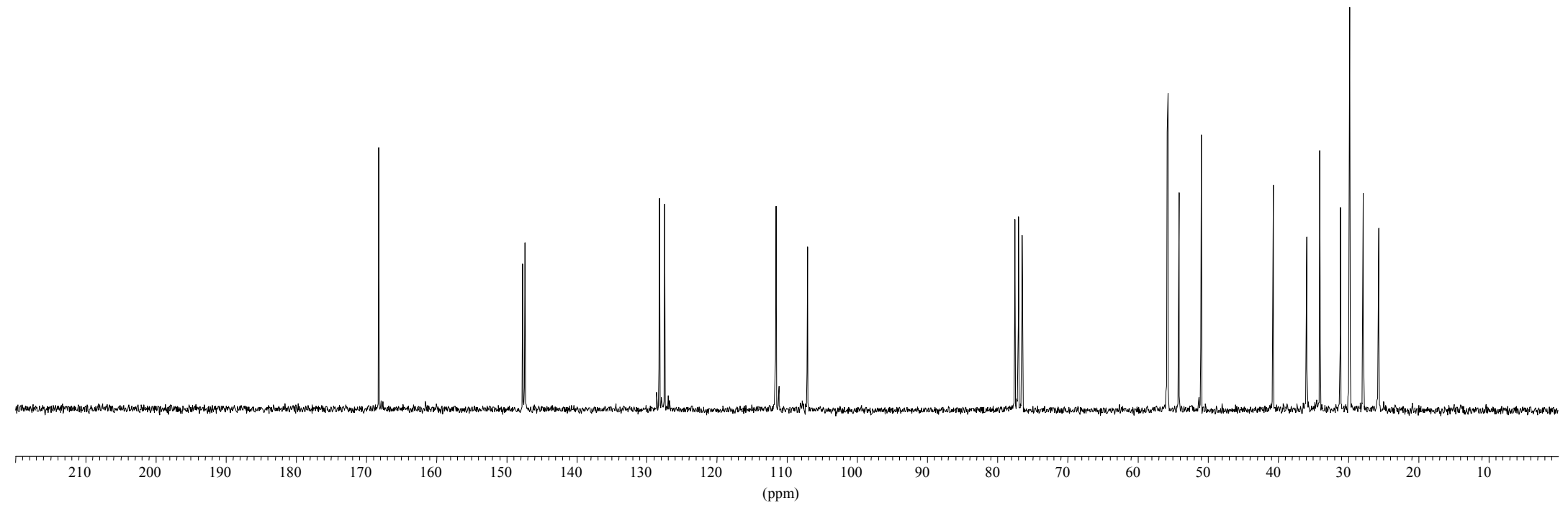



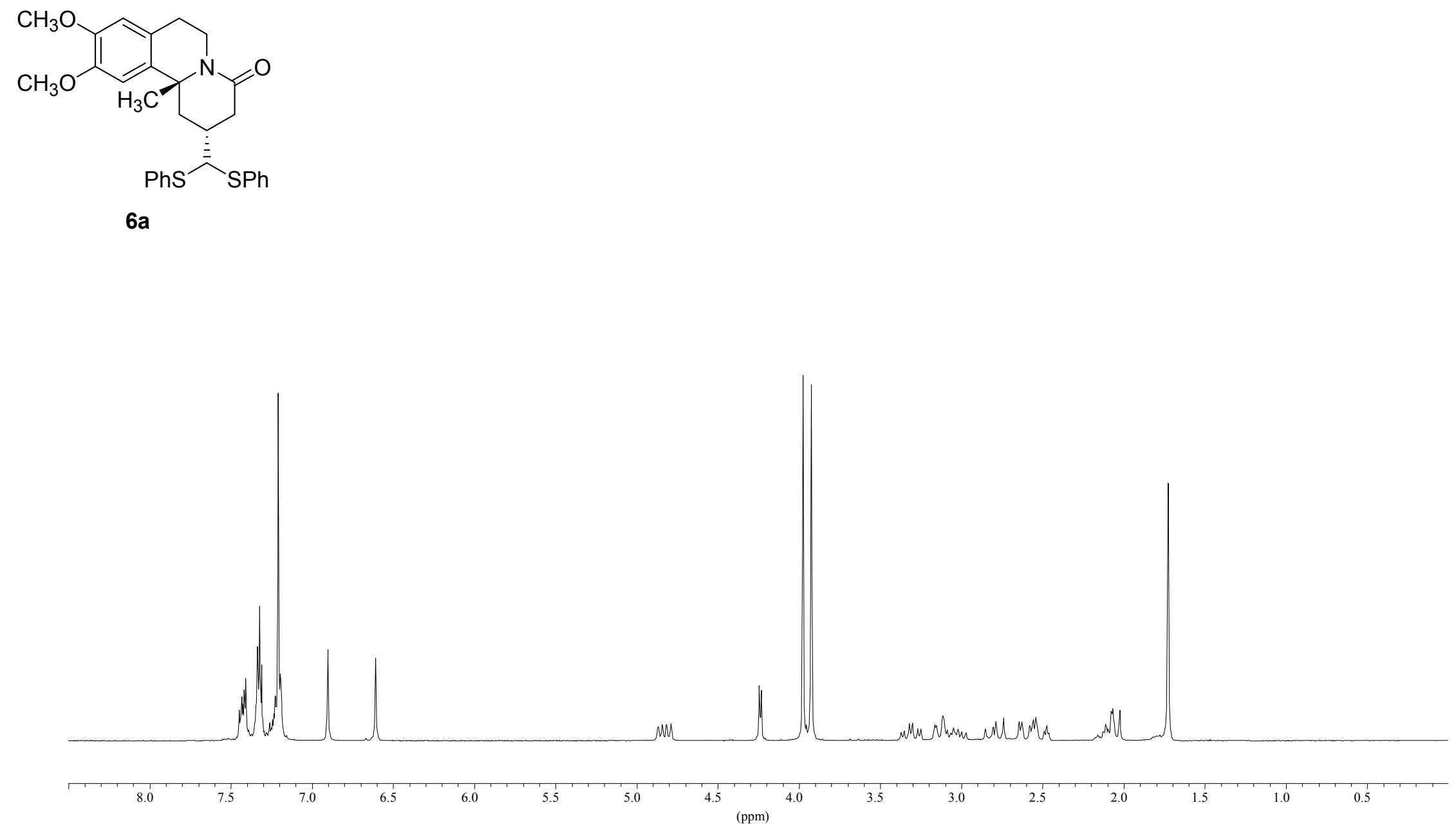

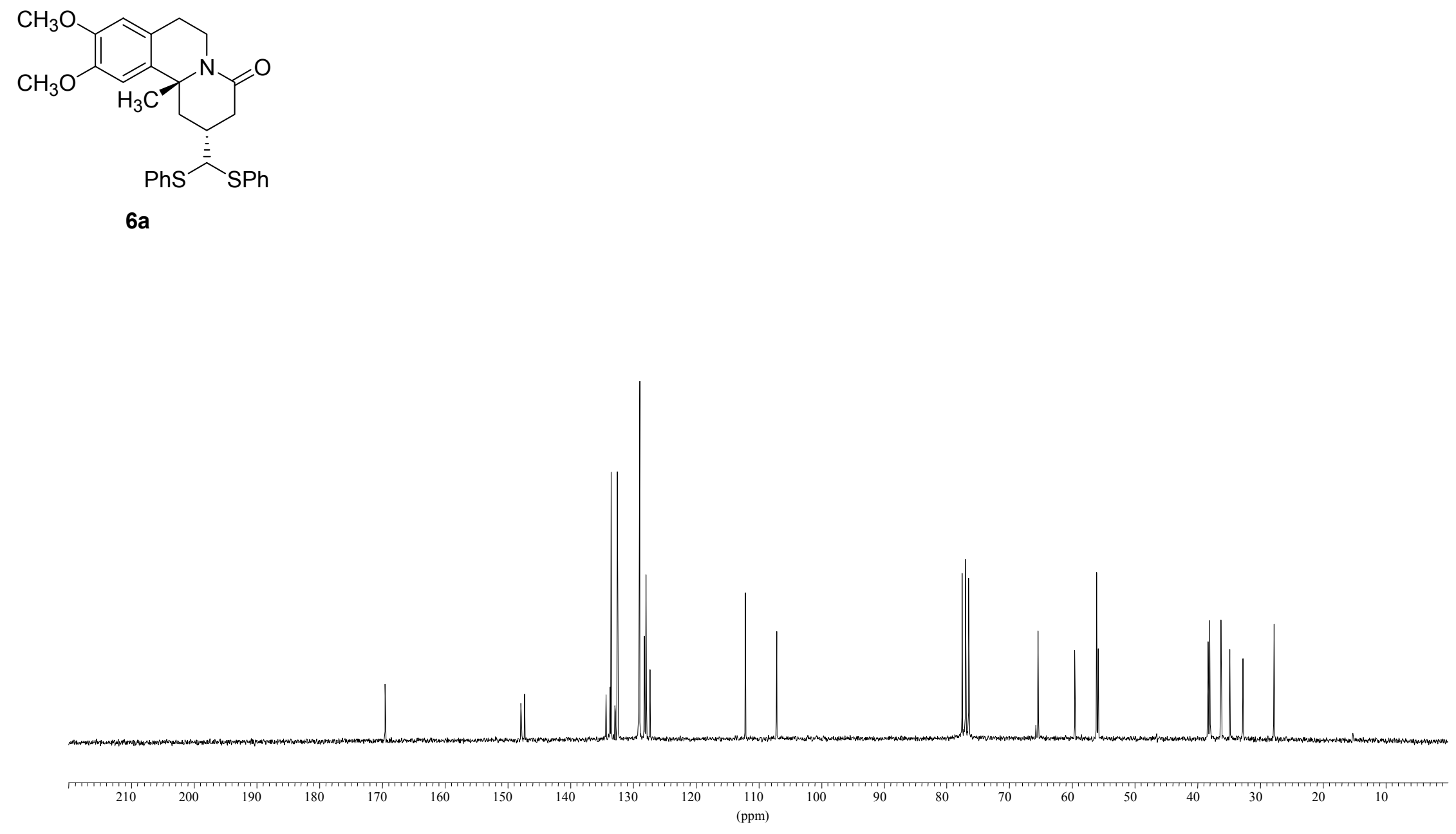

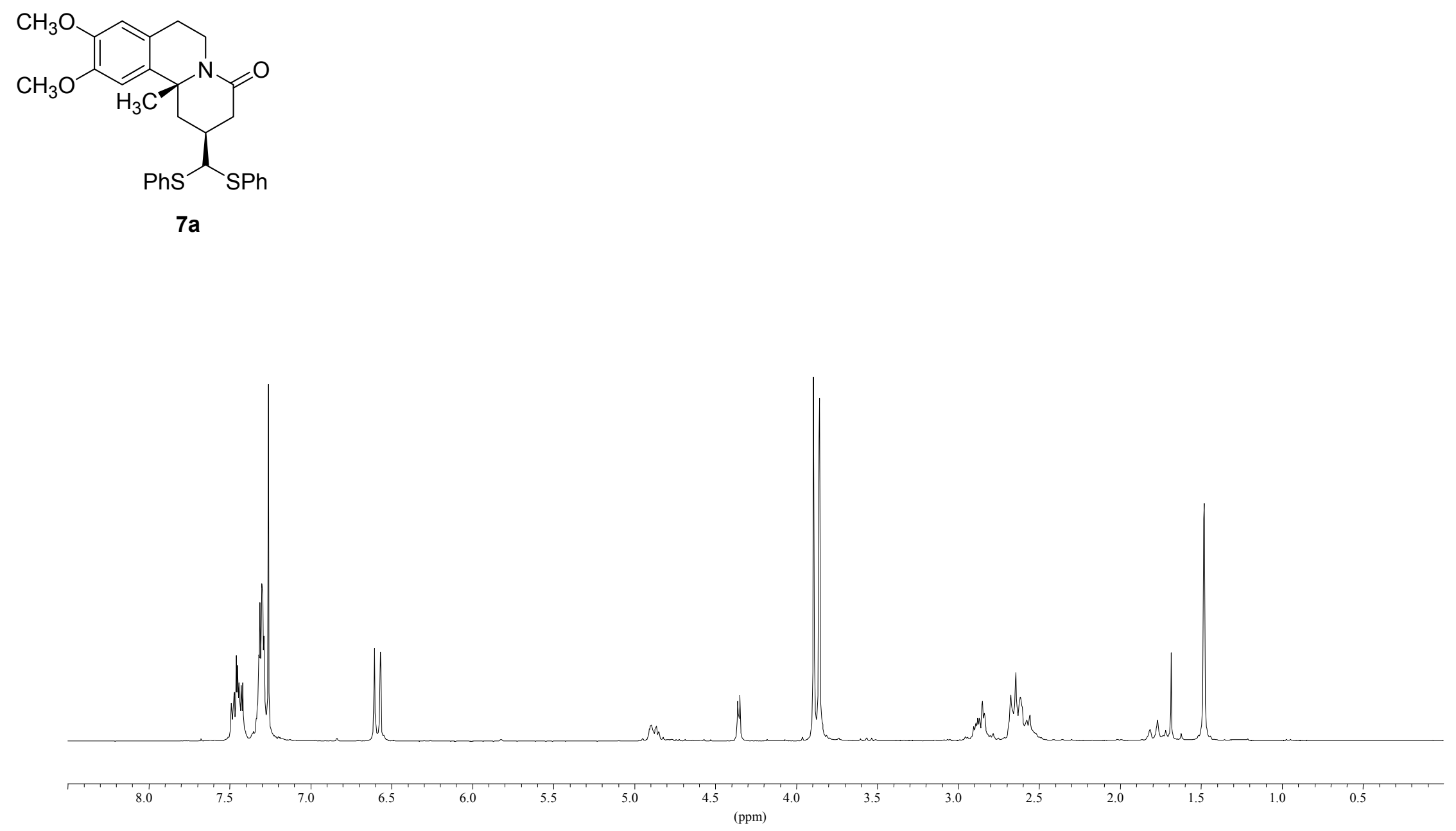

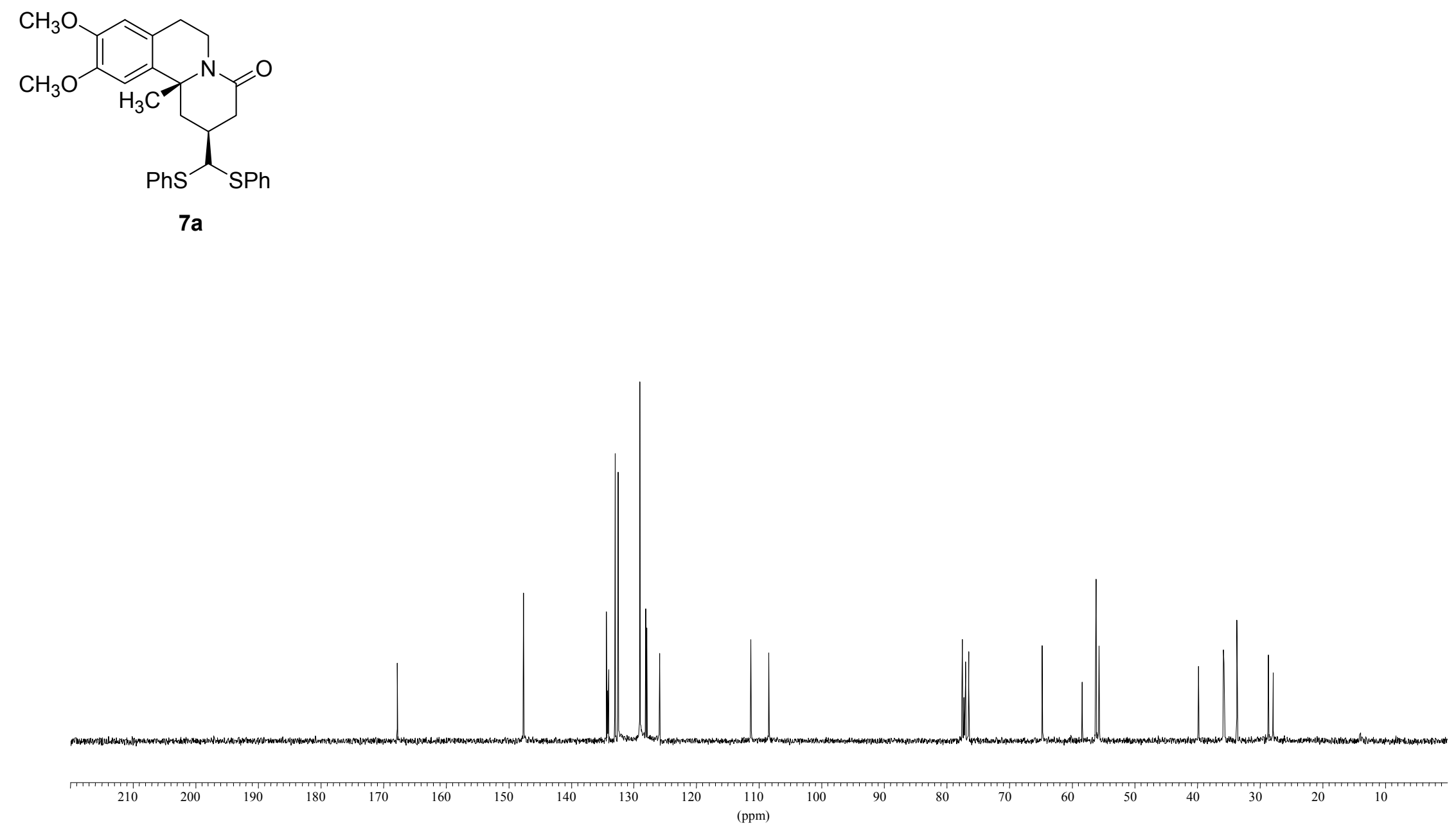


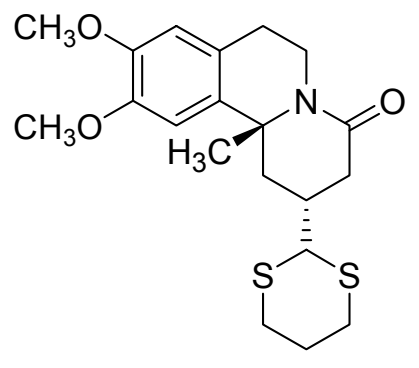

6b

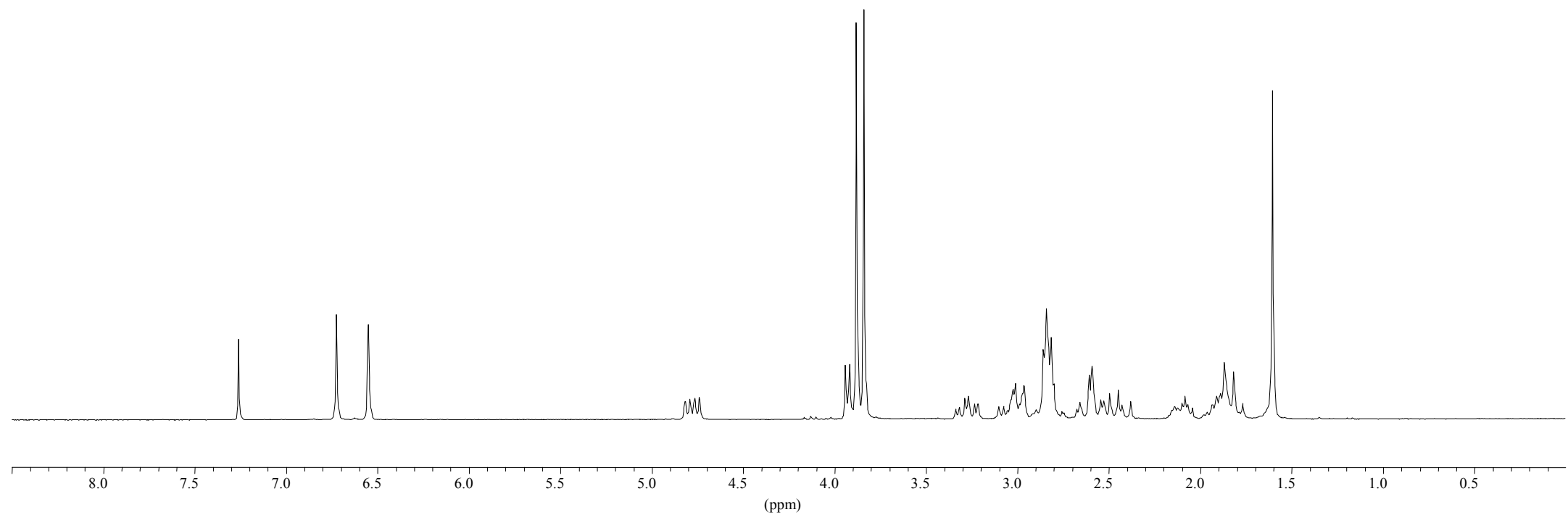

S-28 


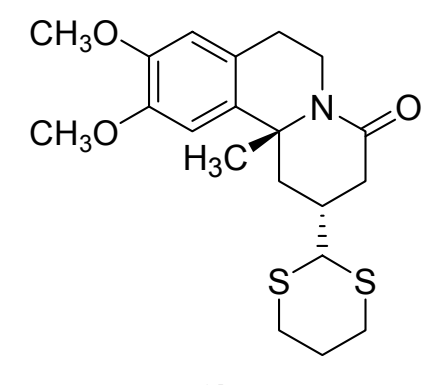

$6 b$

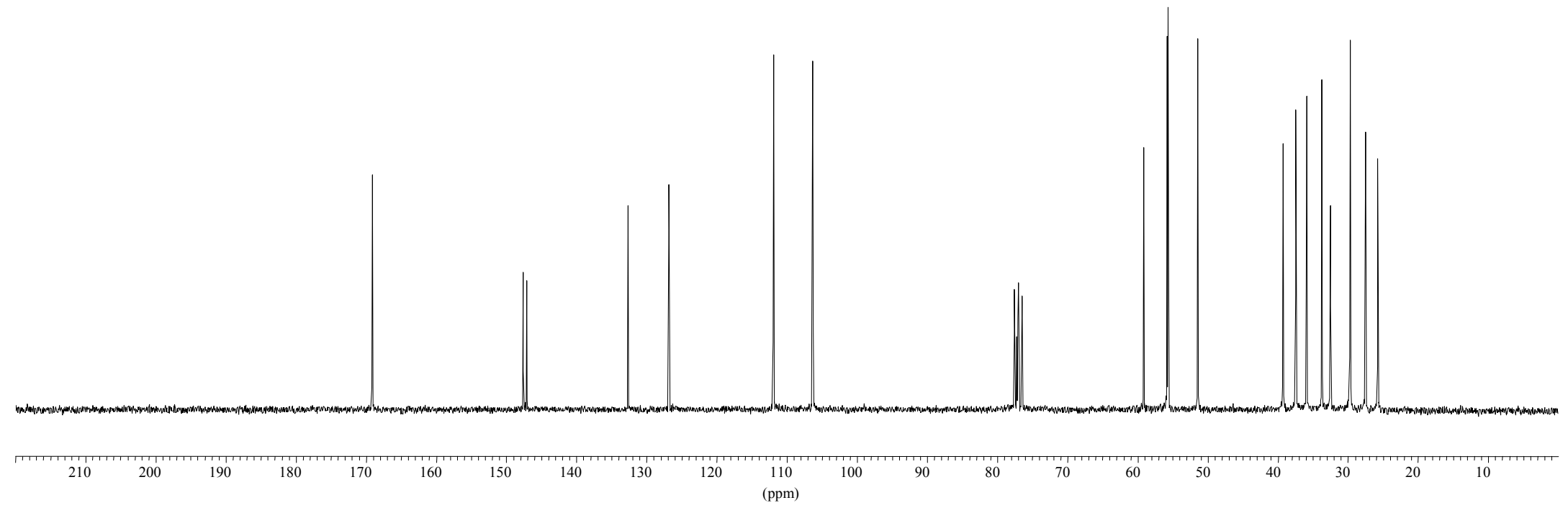




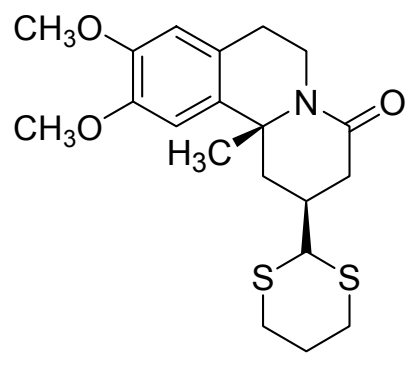

$7 b$

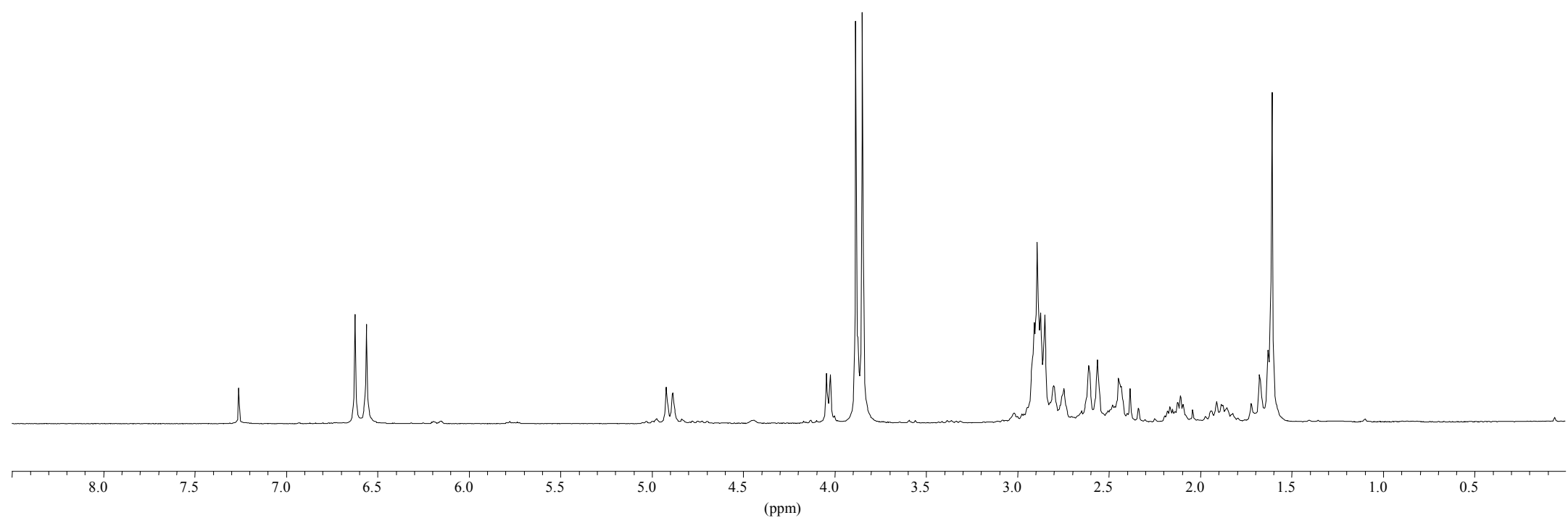

S-30 


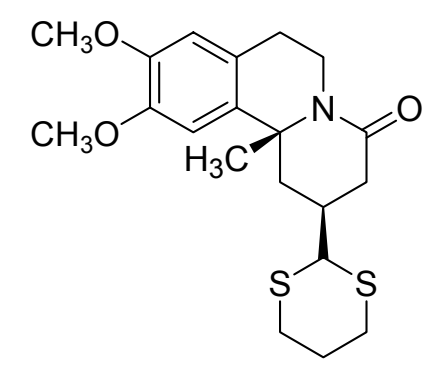

7b

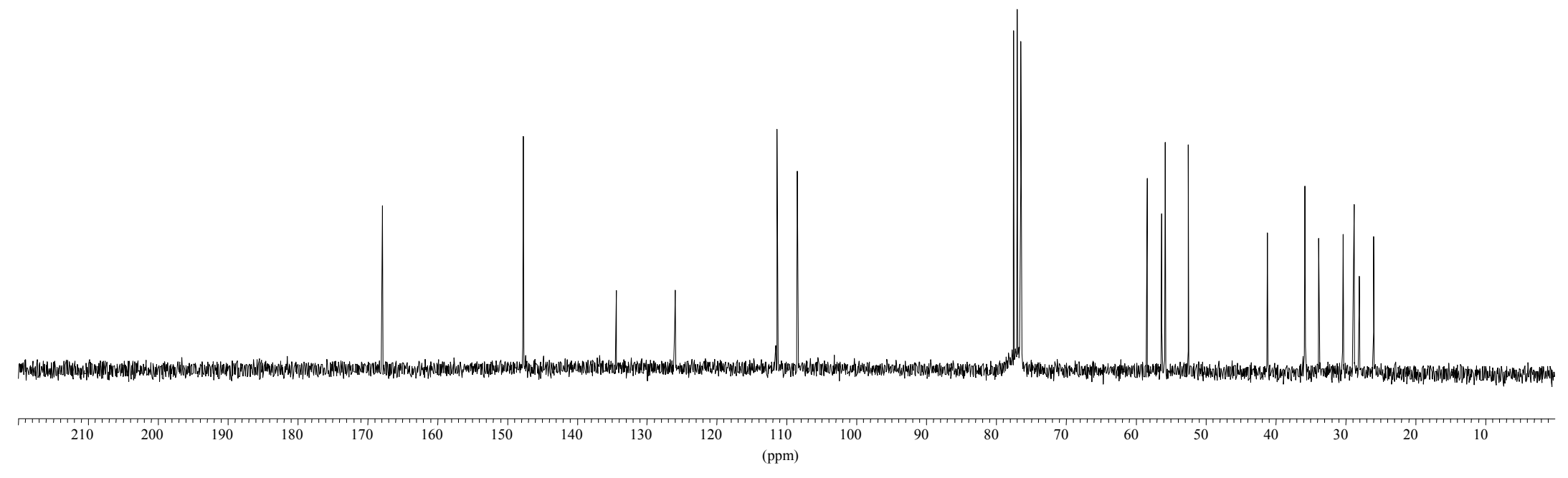




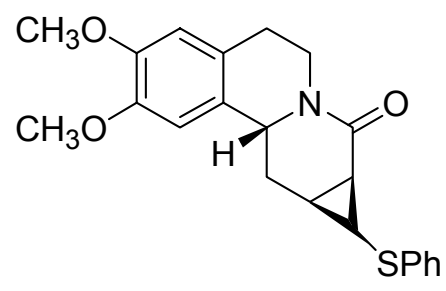

8

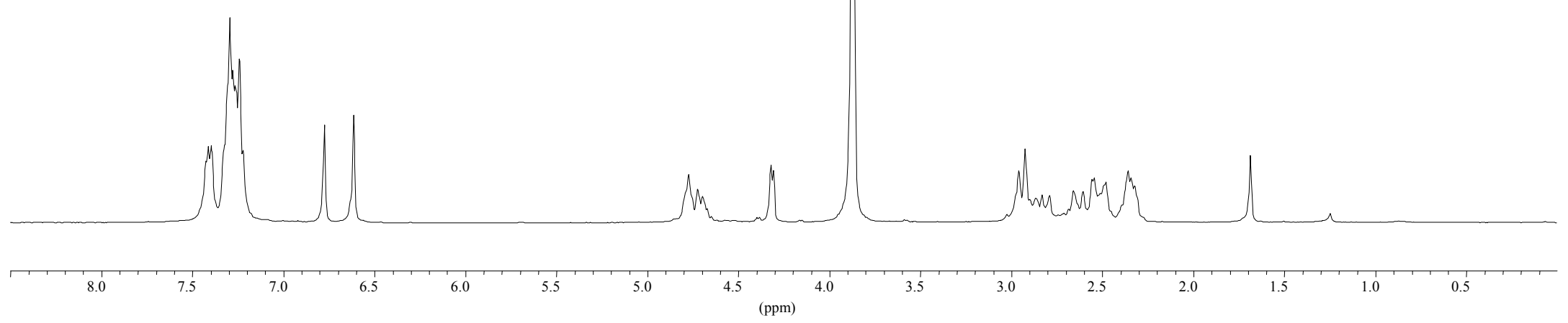

S-32 


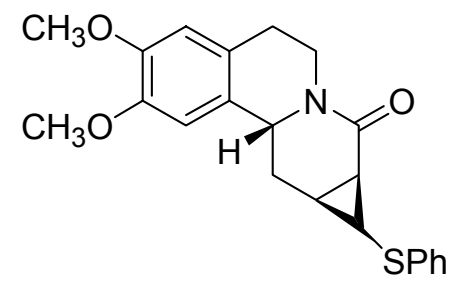

8

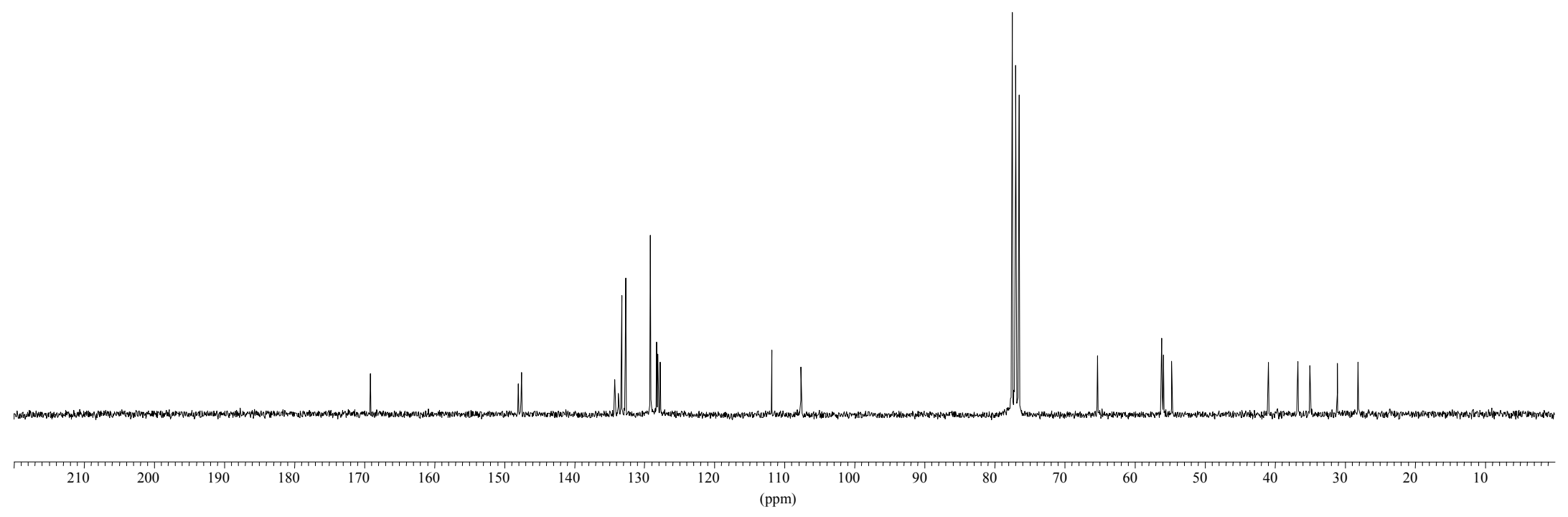

S-33 

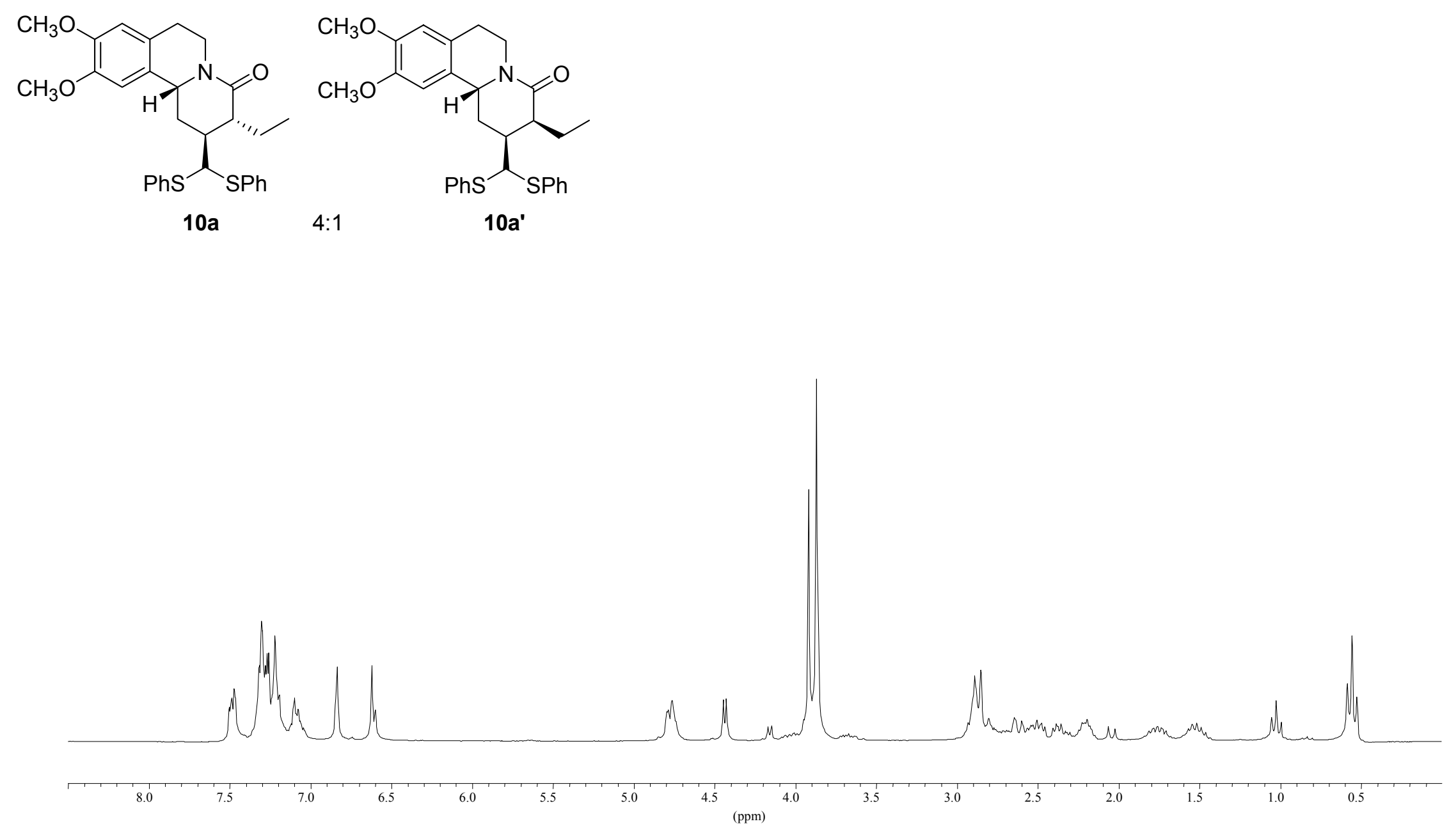

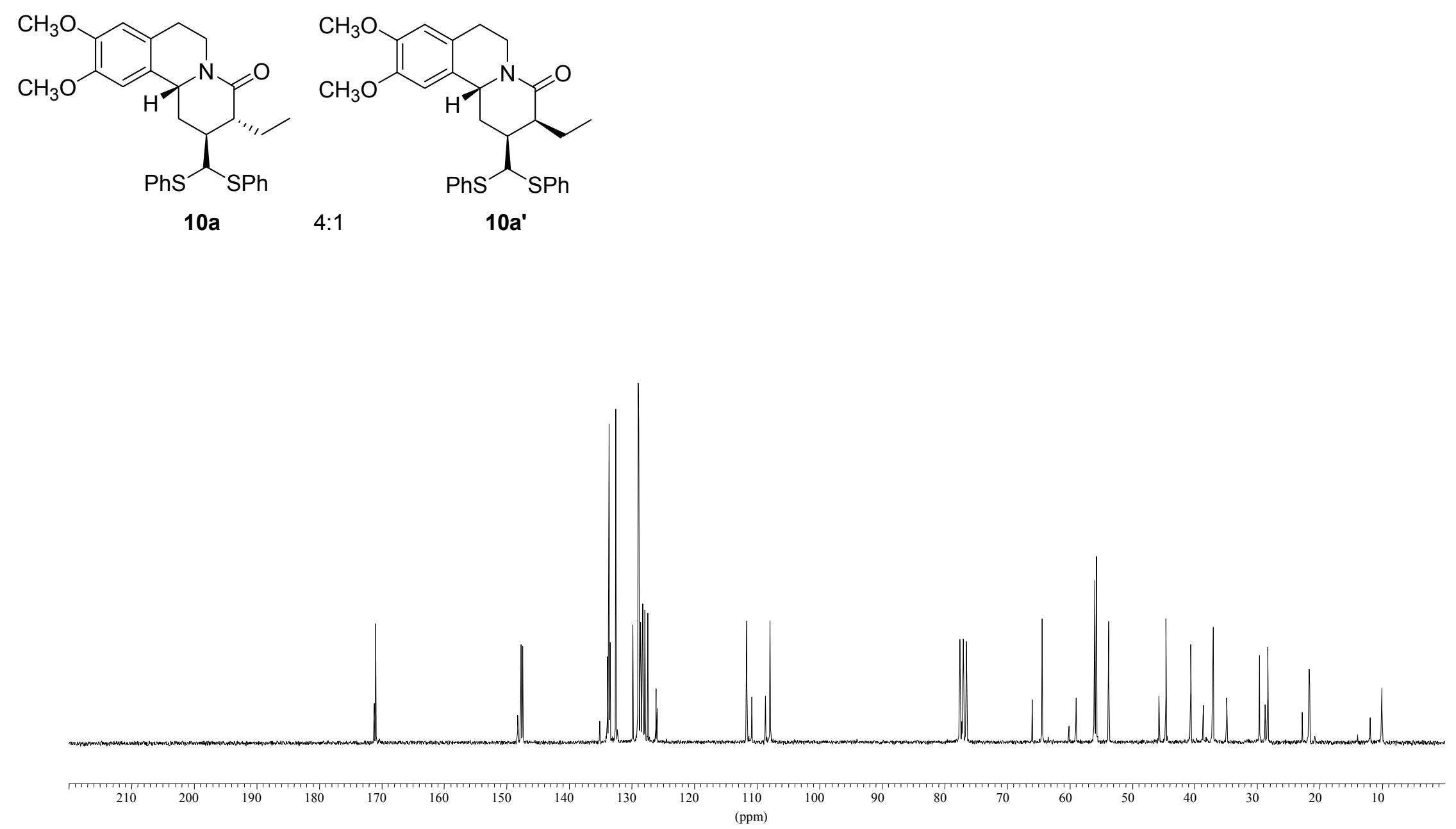

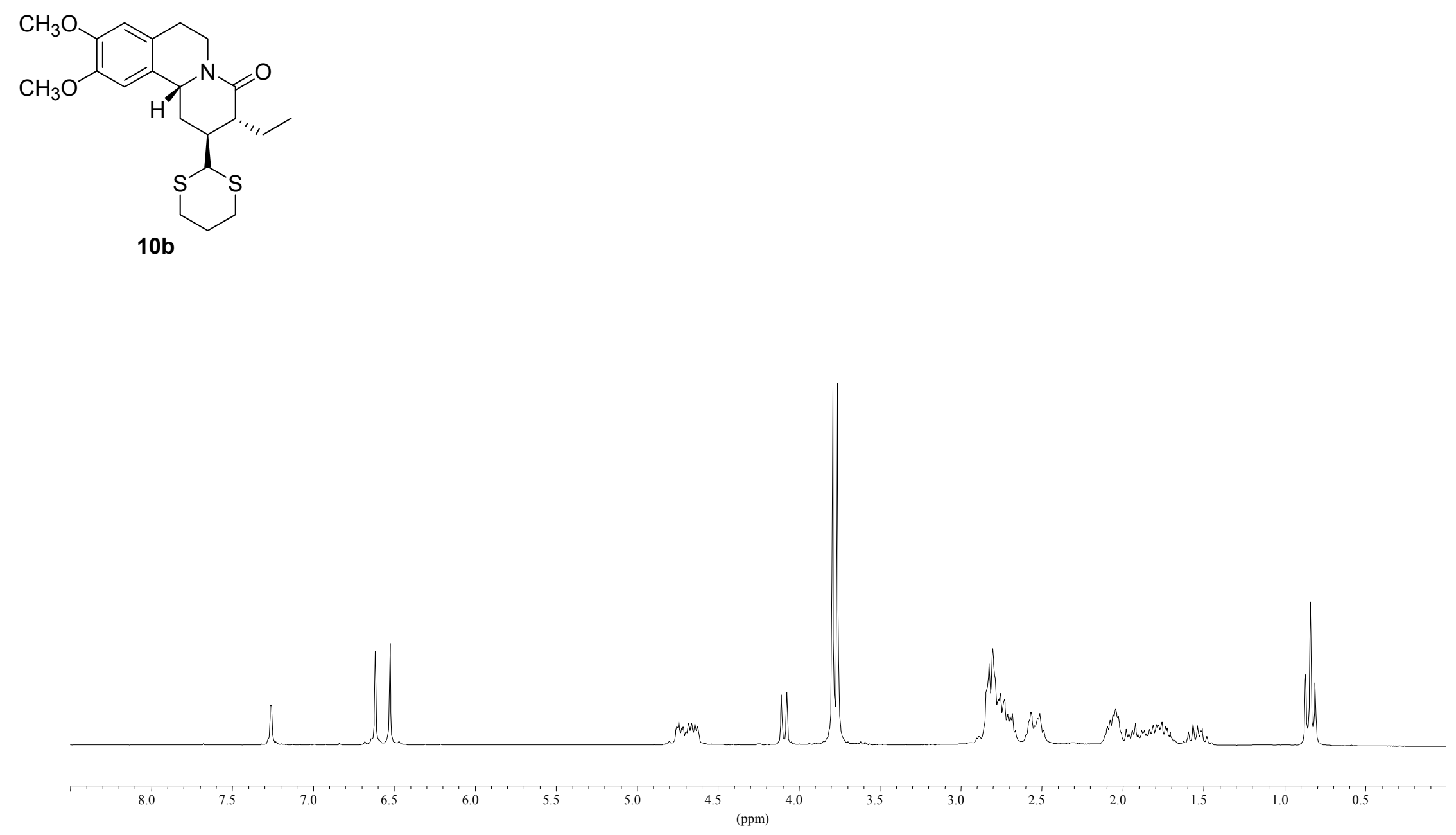

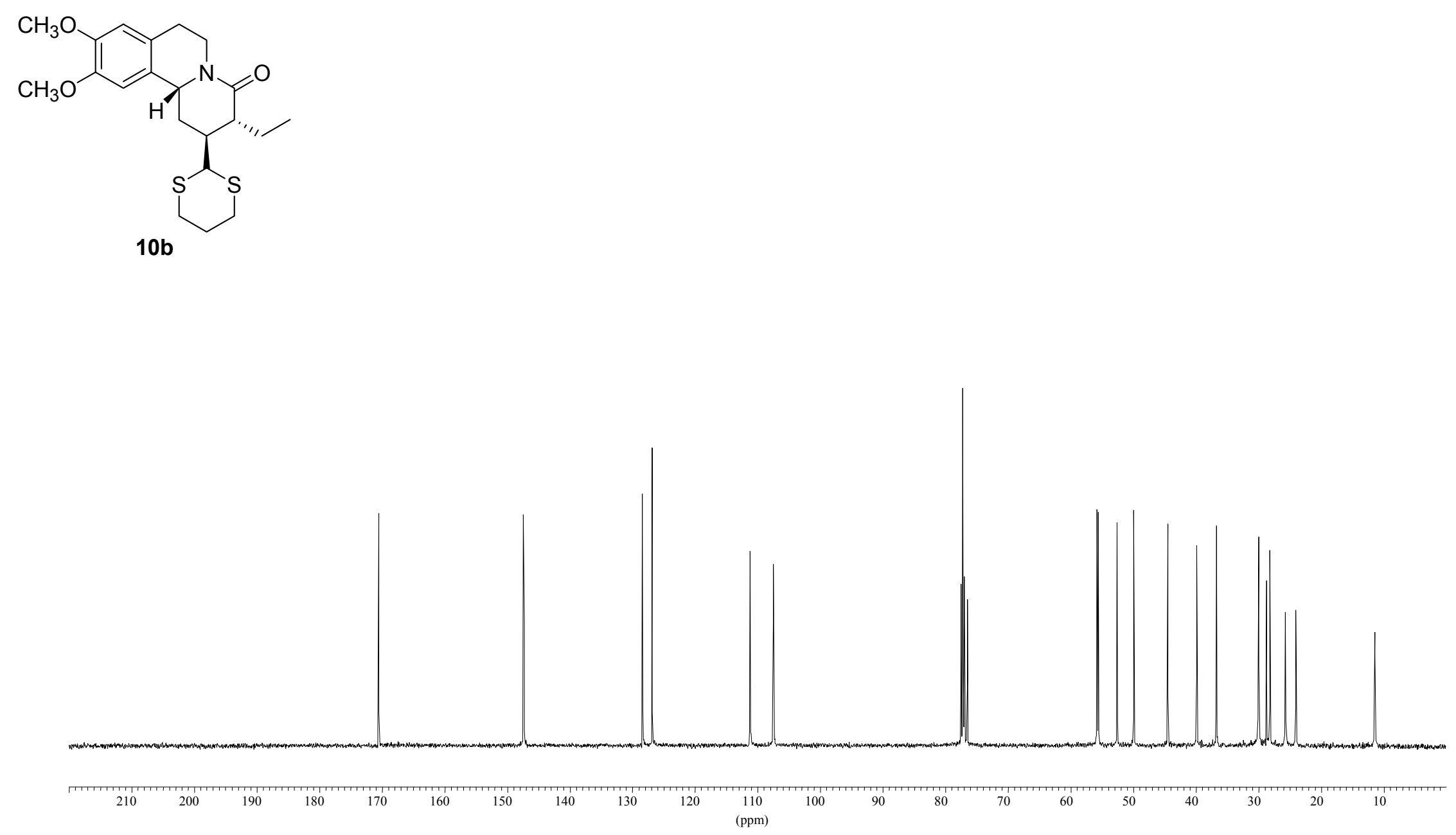


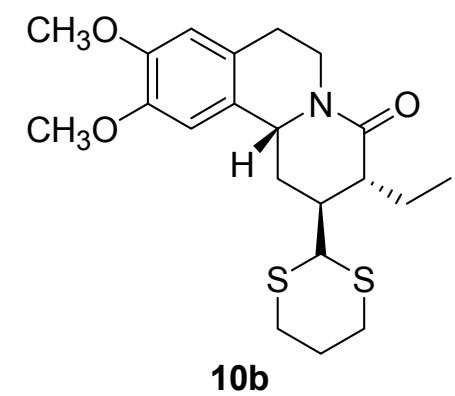

COSY spectrum of $\mathbf{1 0 b}$

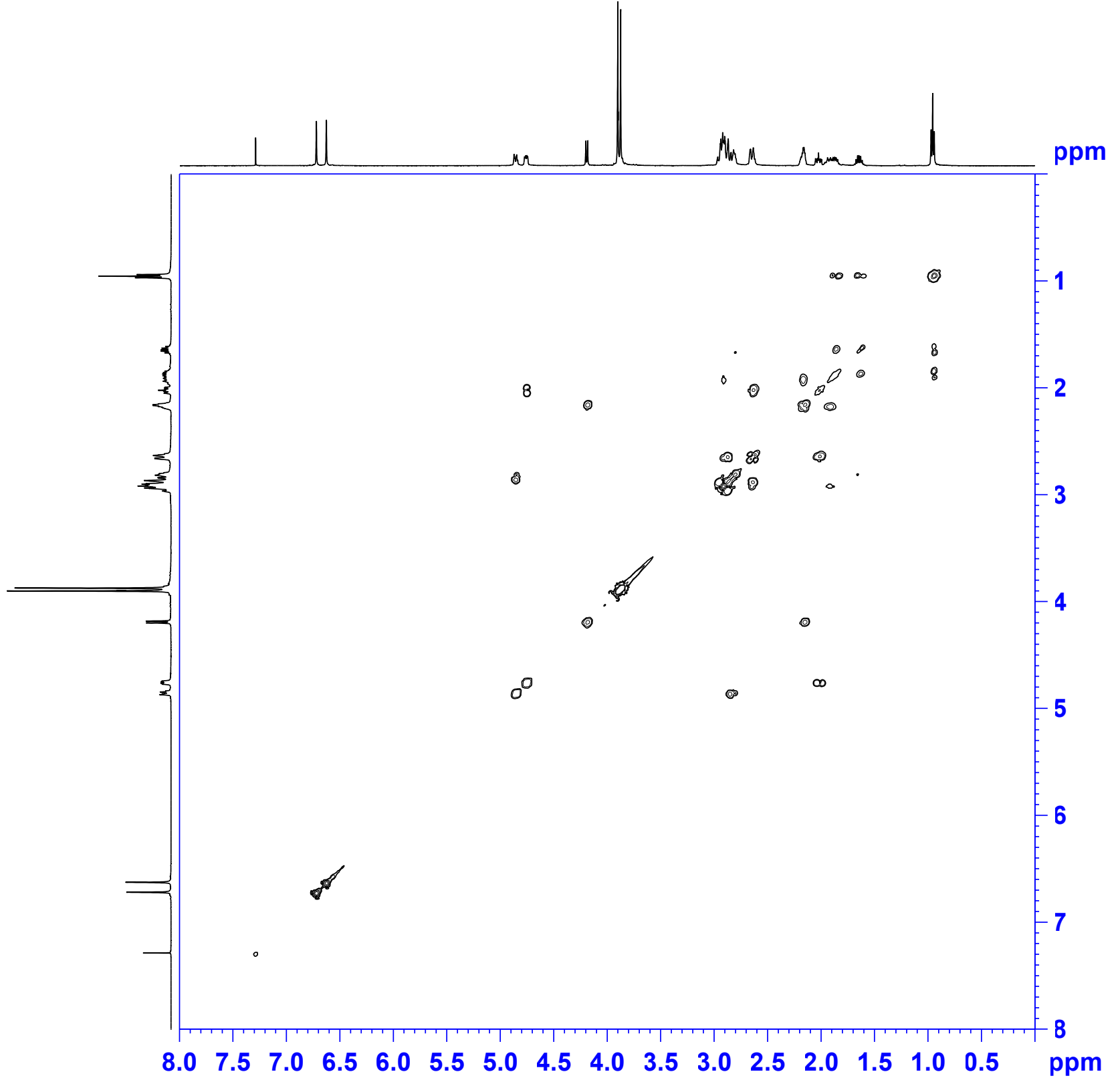

S-38 


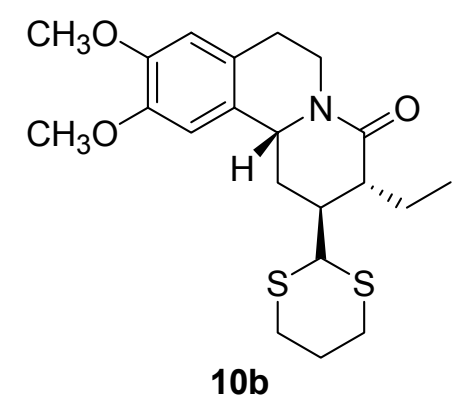

NOESY spectrum of $\mathbf{1 0 b}$

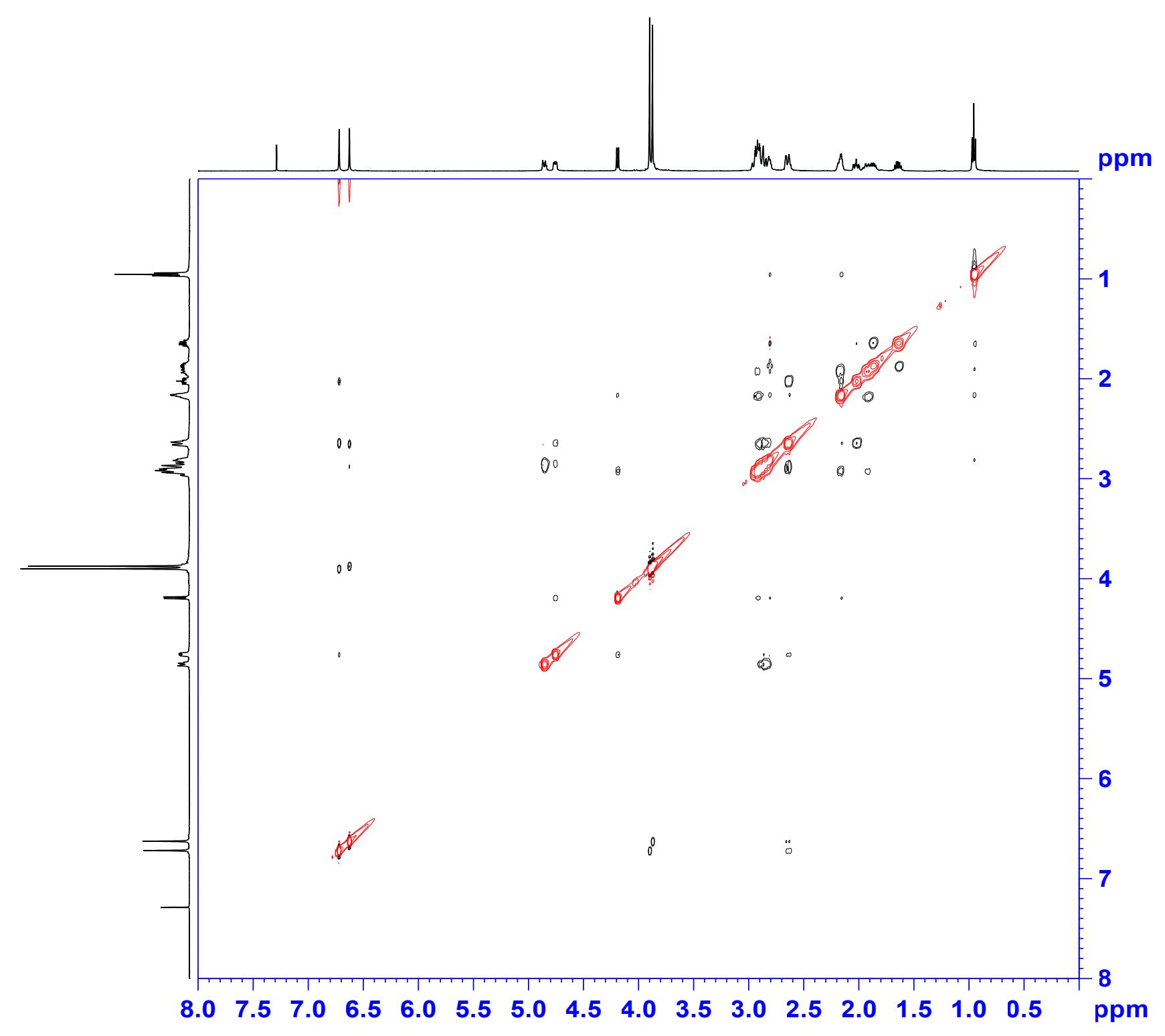




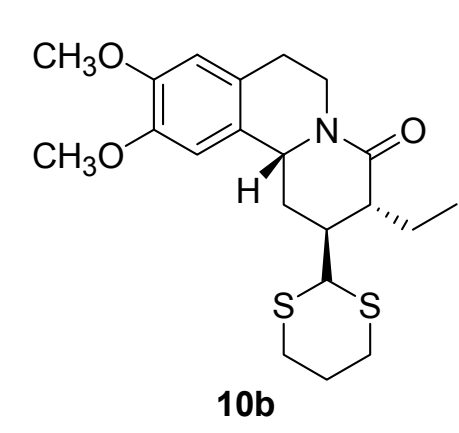

HMQC spectrum of $\mathbf{1 0 b}$

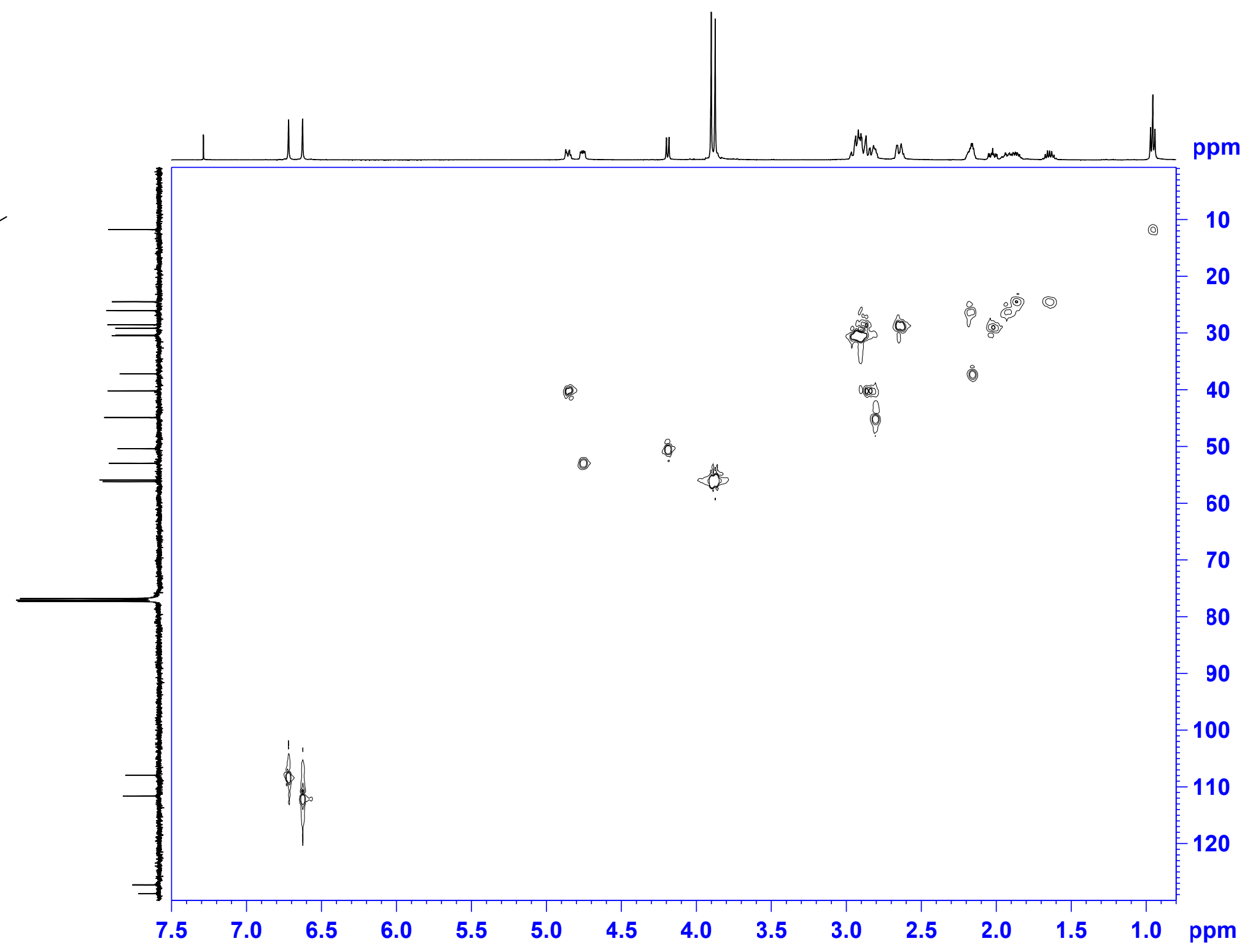



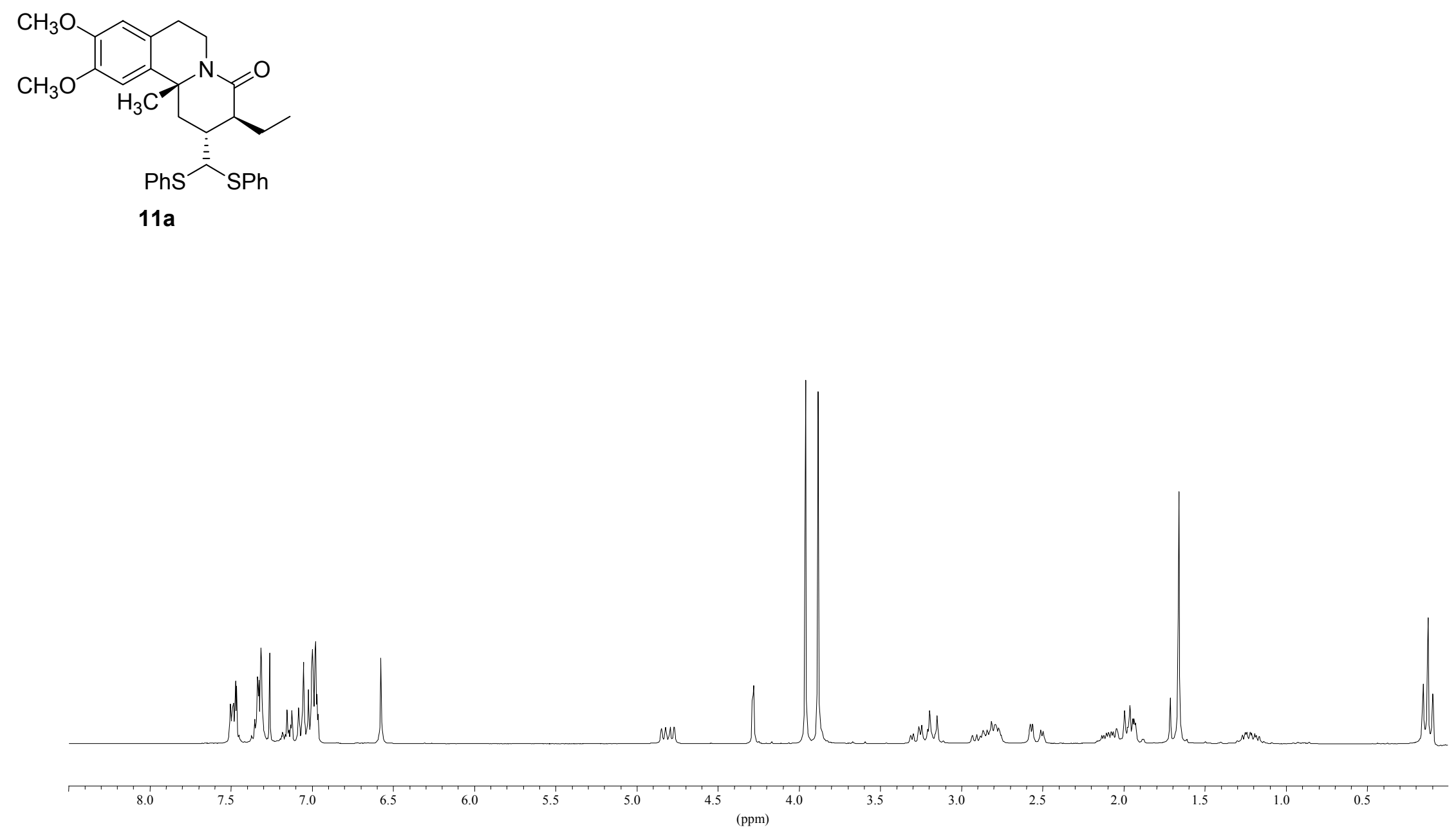

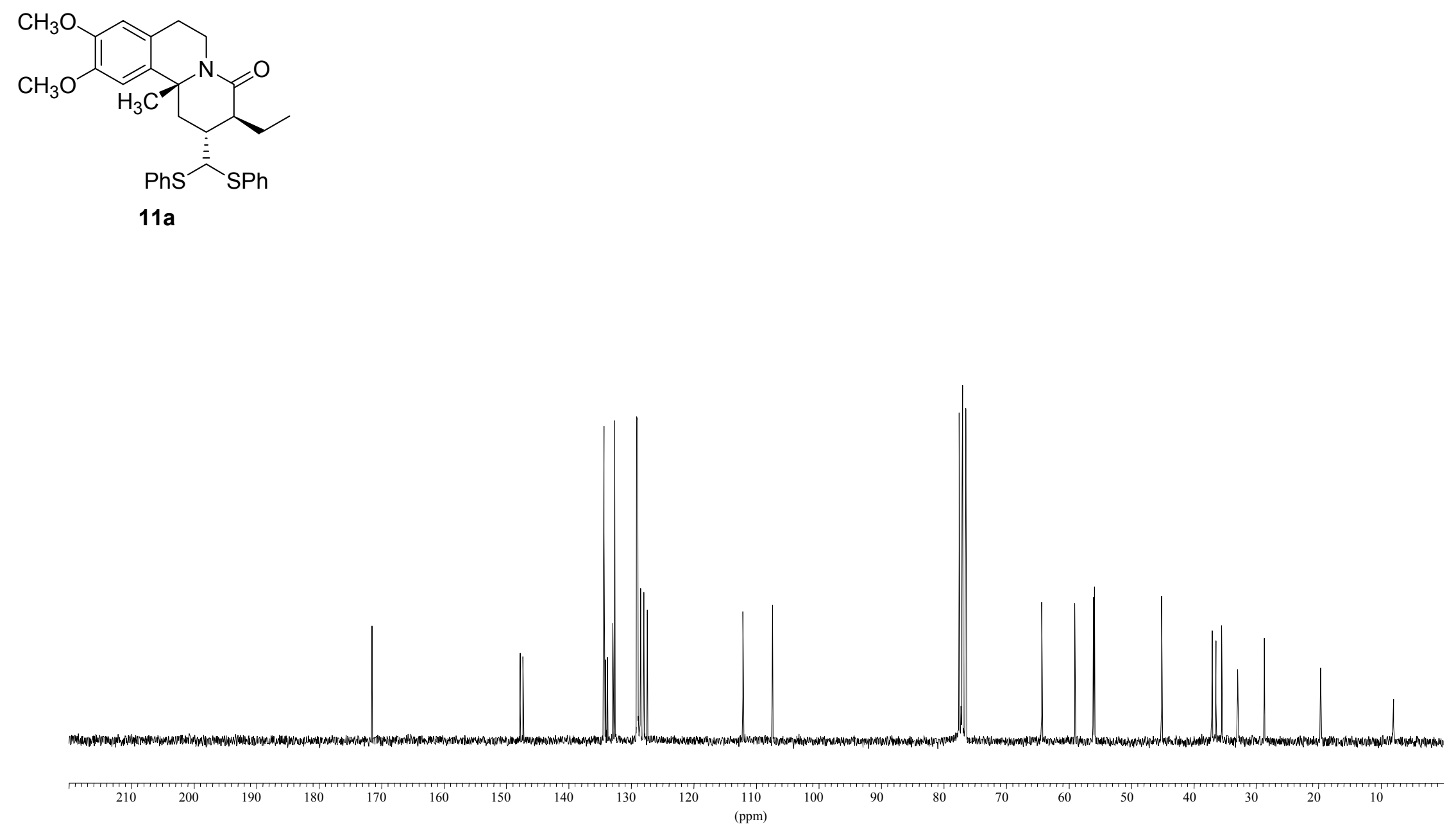

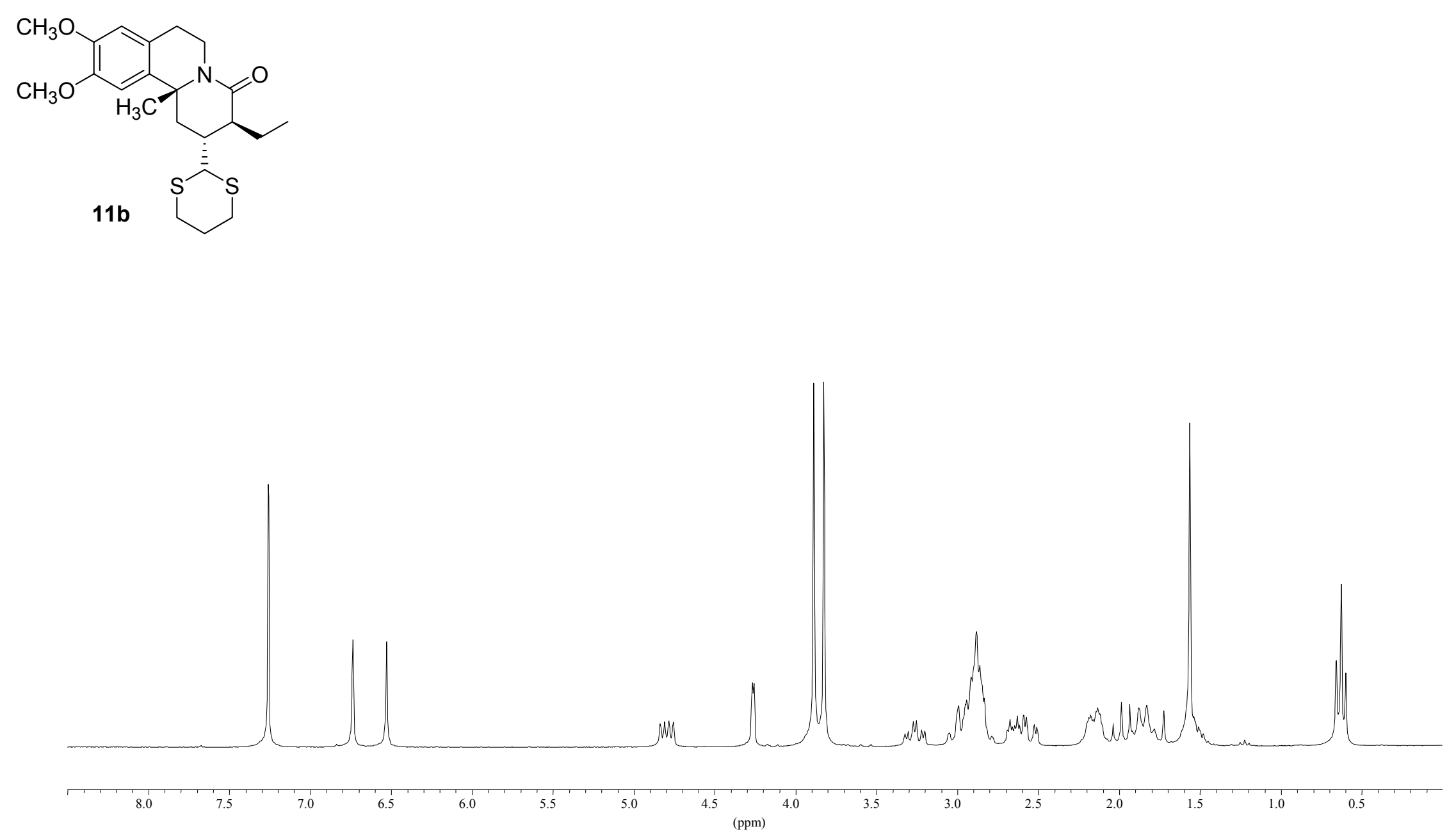

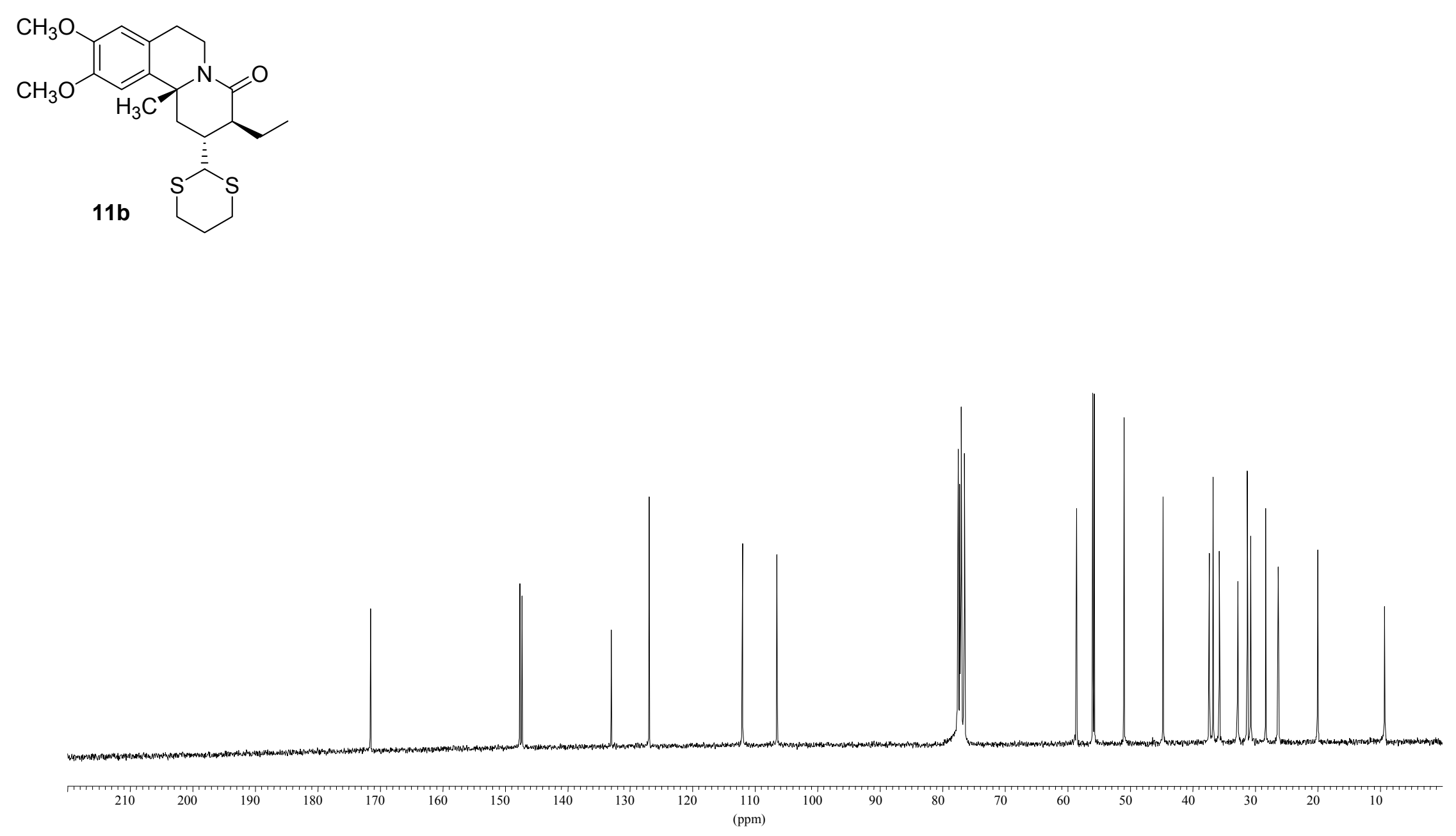


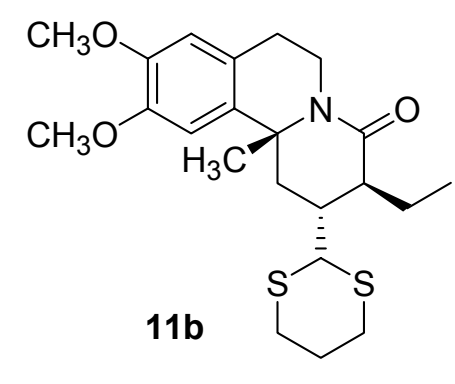

COSY spectrum of $\mathbf{1 1 b}$

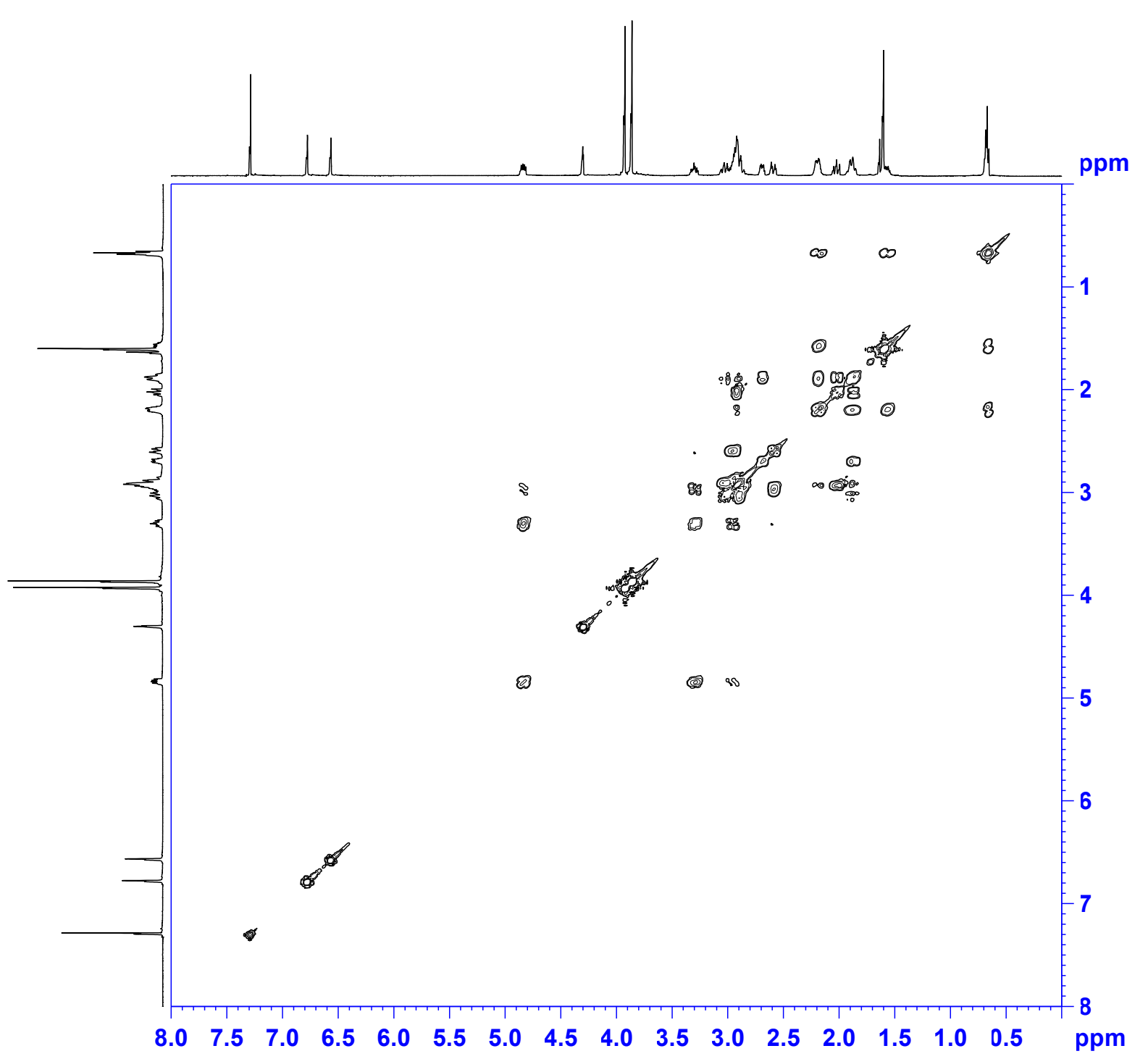

S-45 


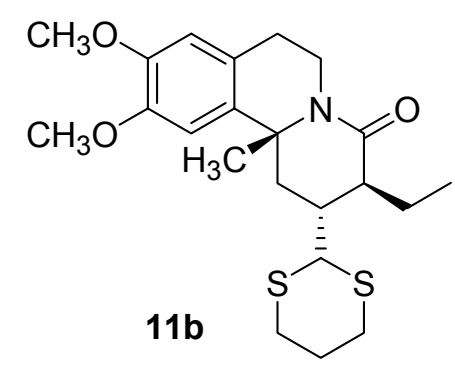

NOESY spectrum of $\mathbf{1 1 b}$

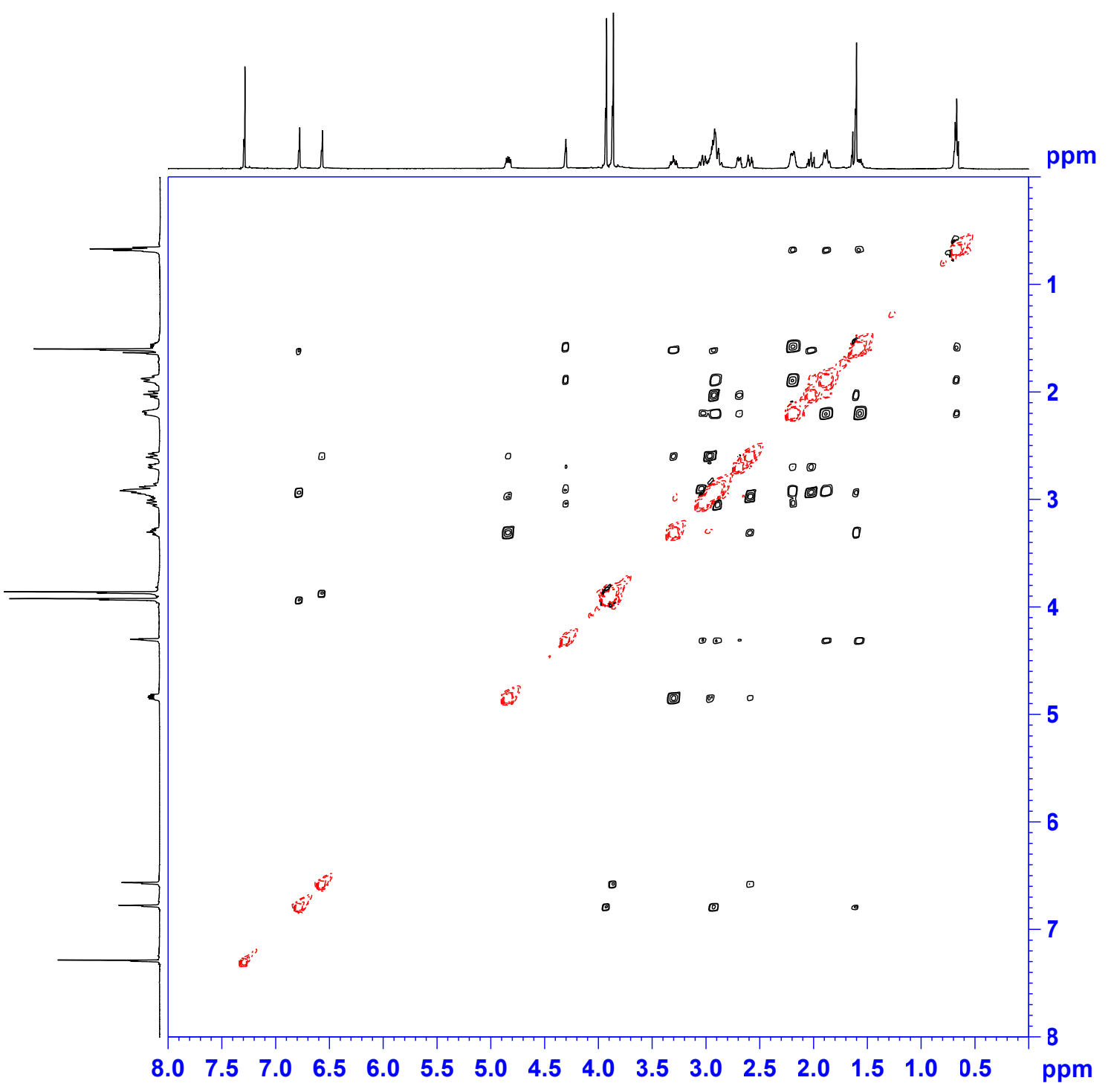




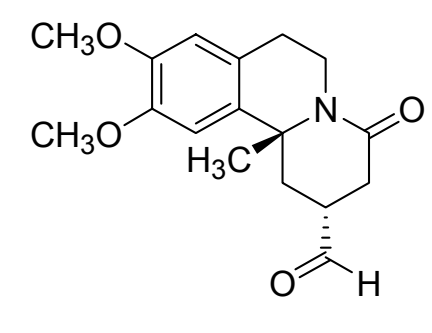

15

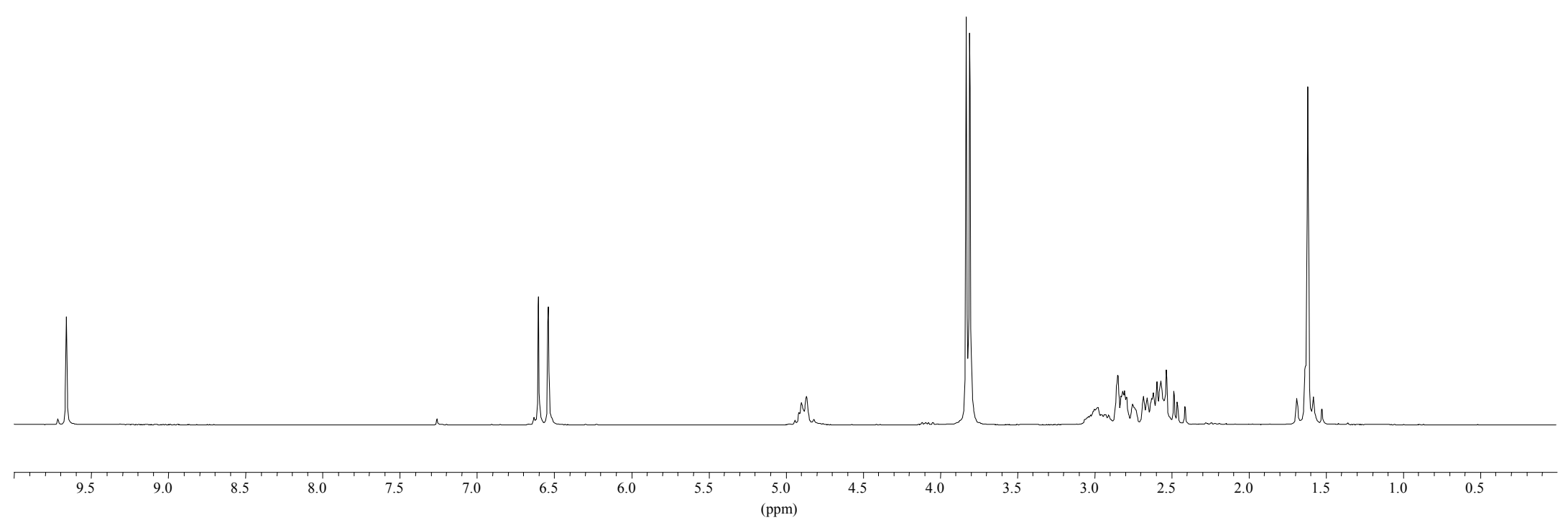




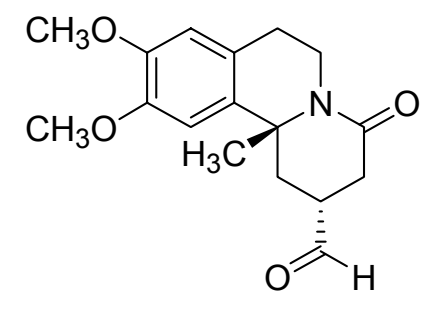

15

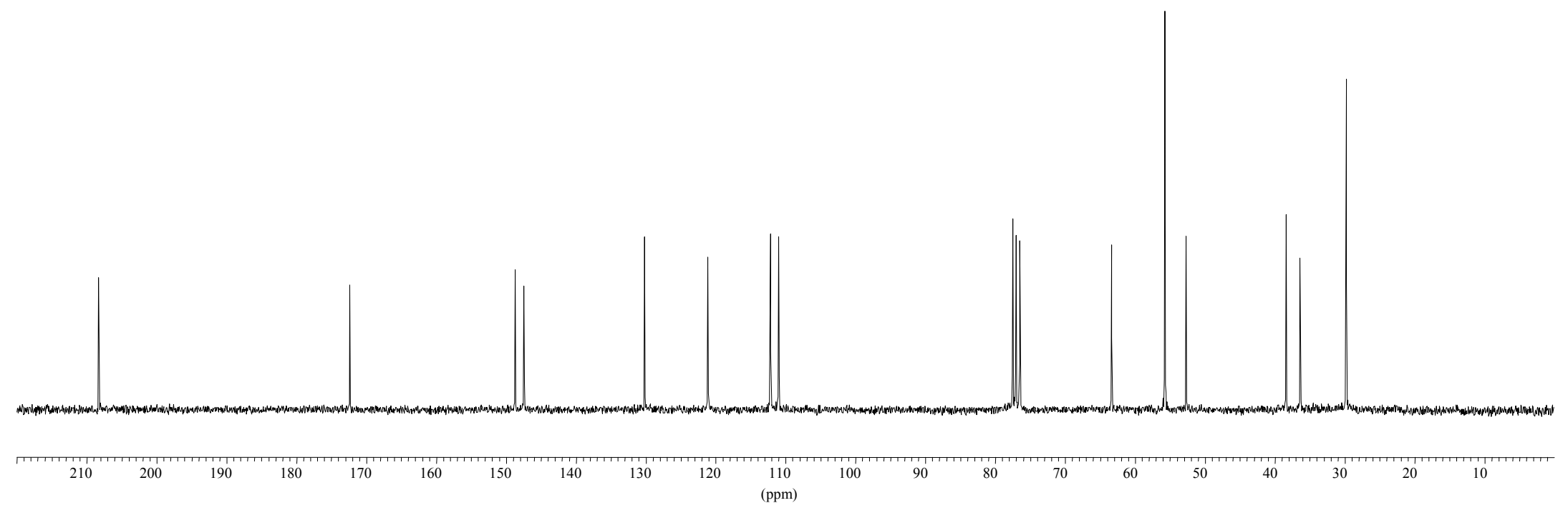



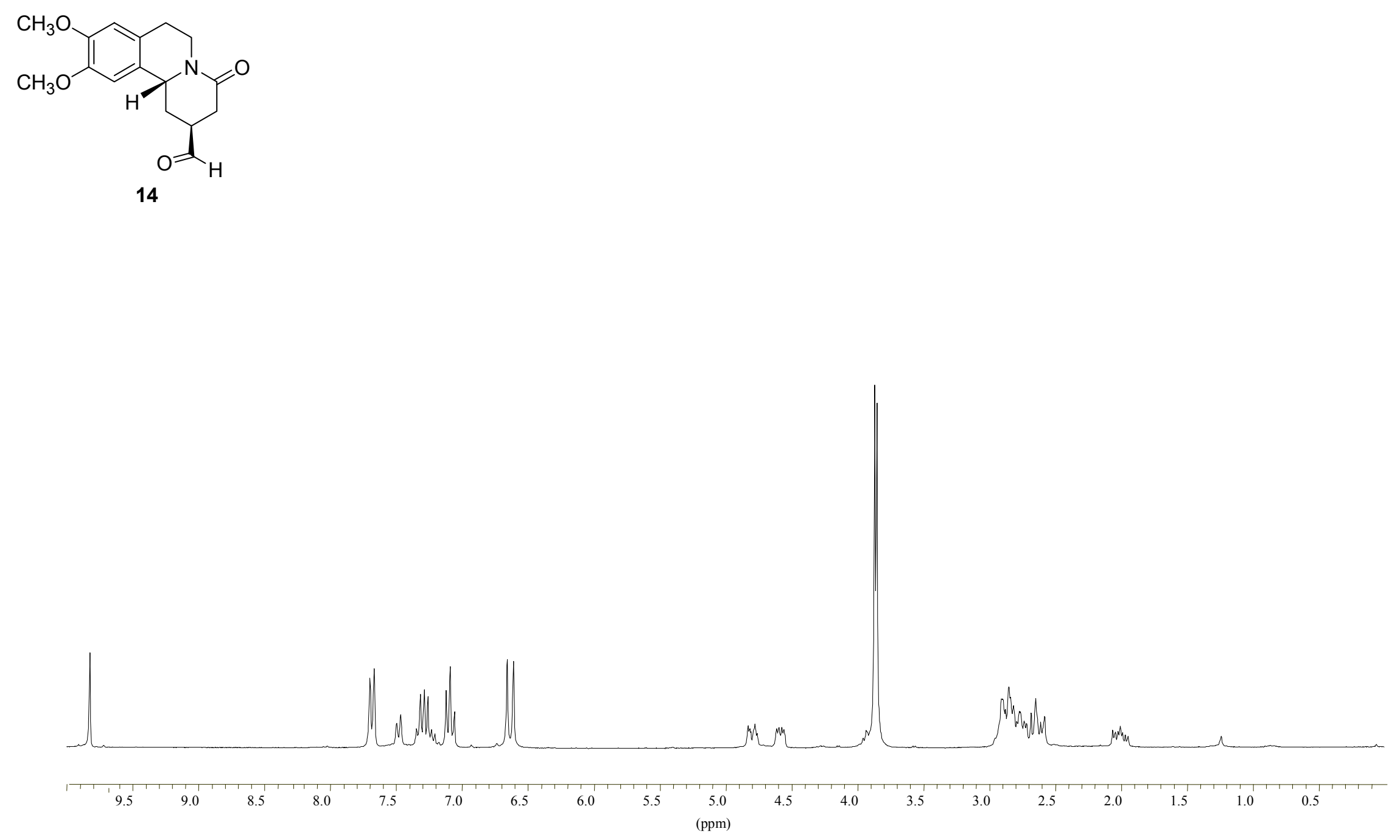

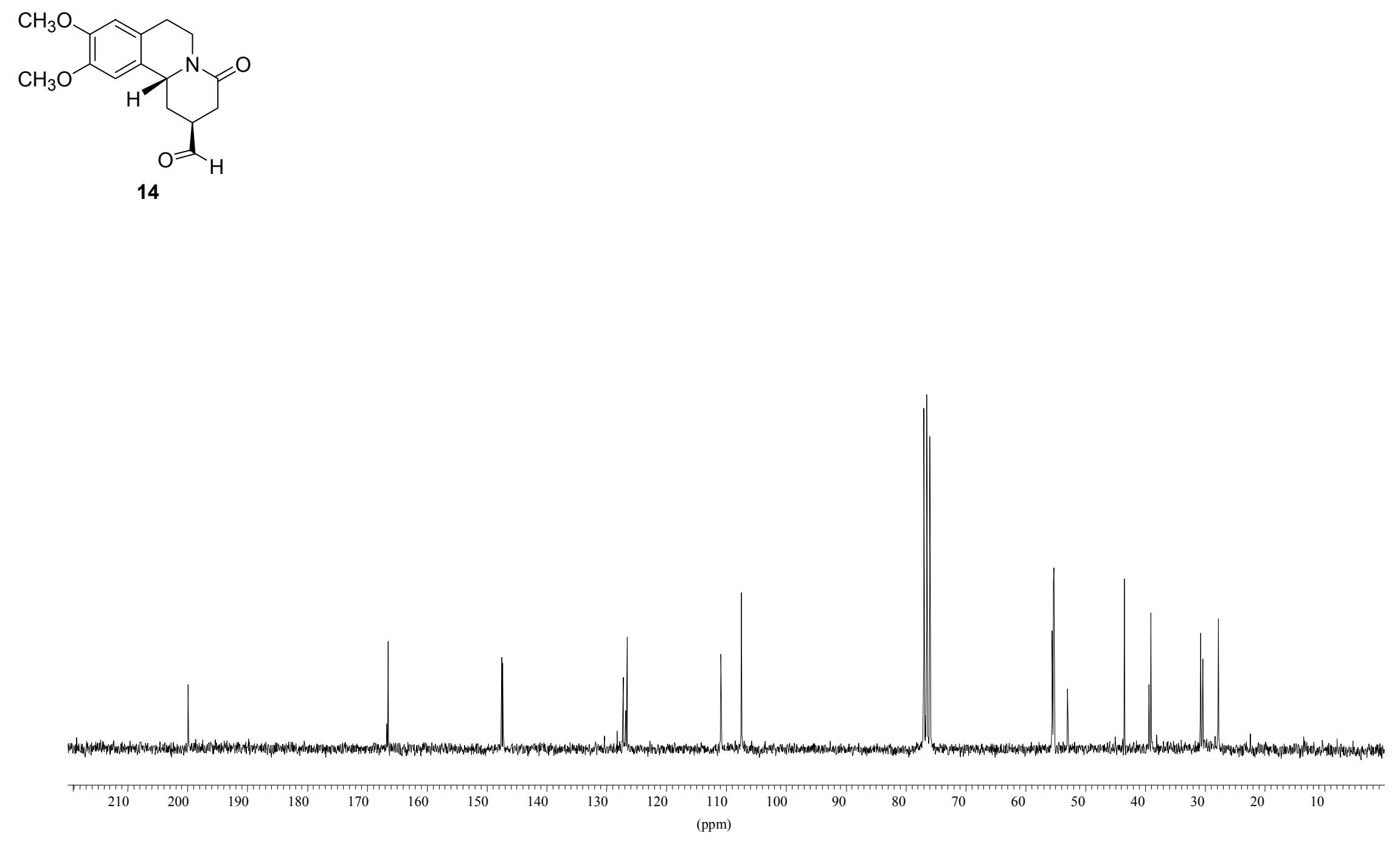


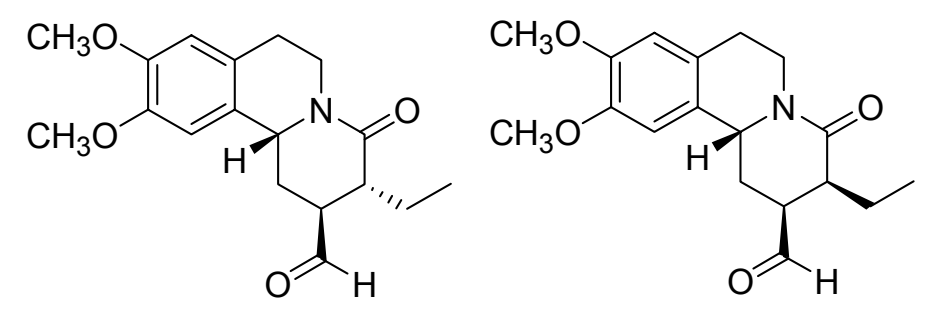

16 (dr 4:1)

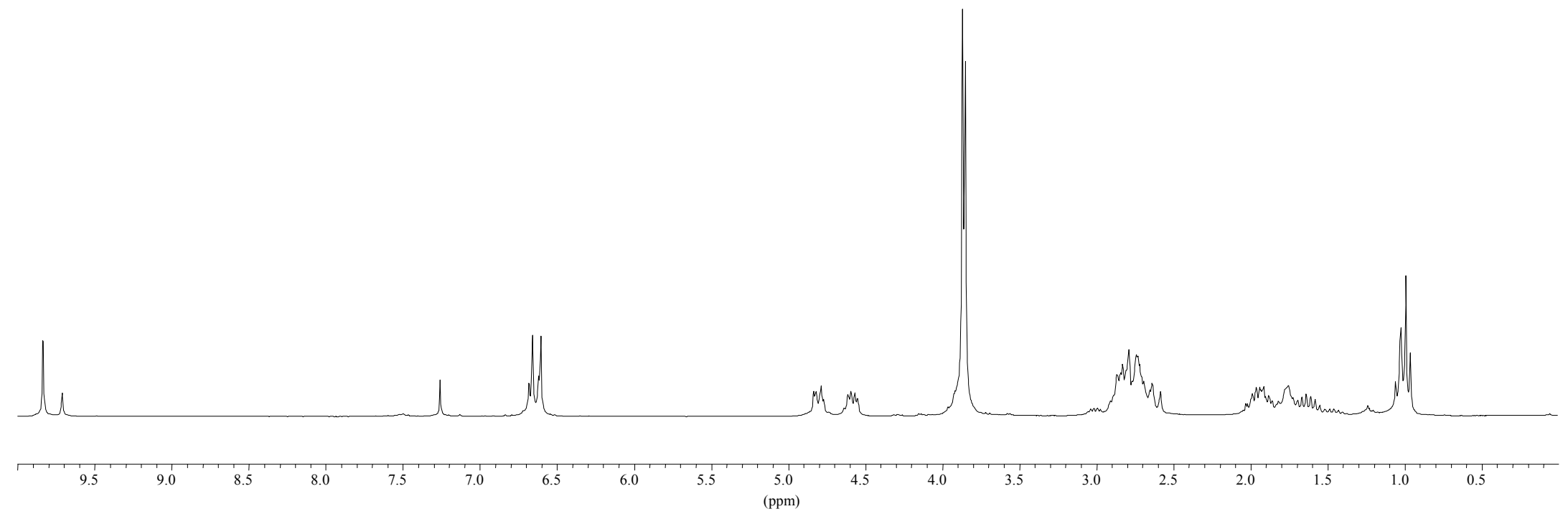




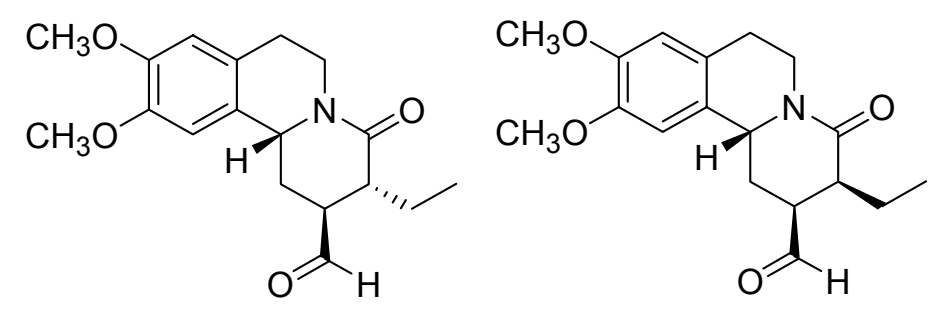

$16(d r 4: 1)$

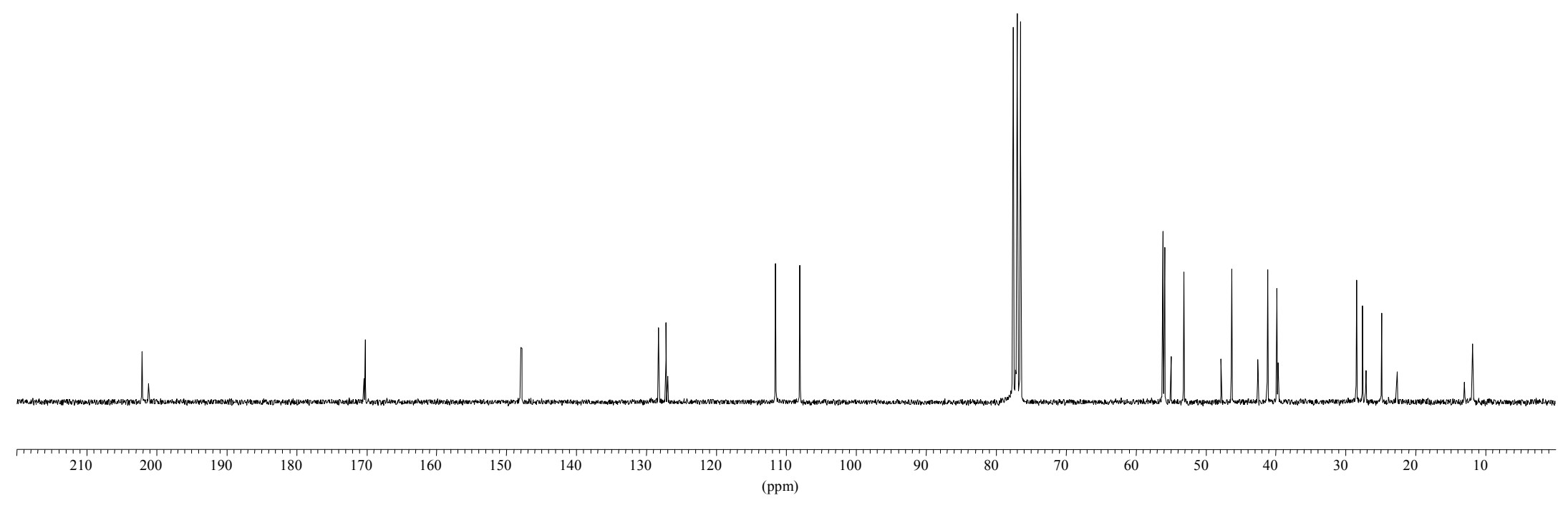




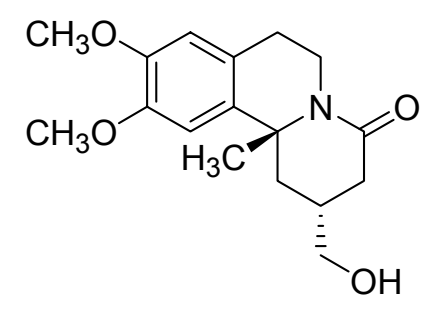

17

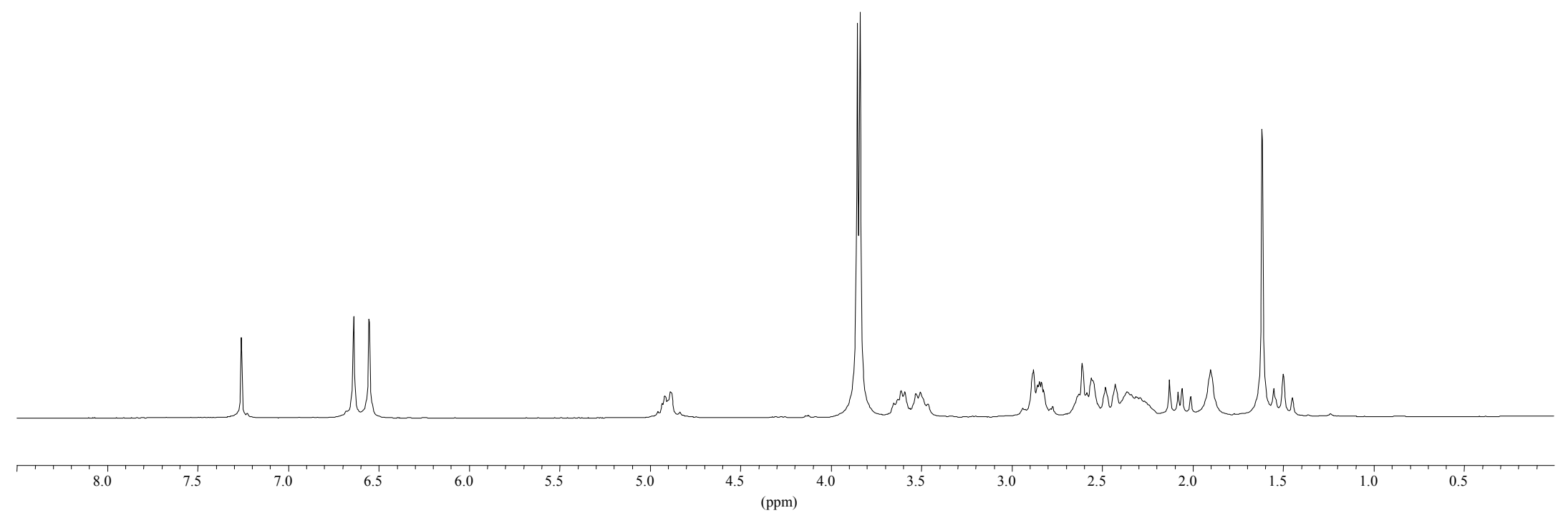




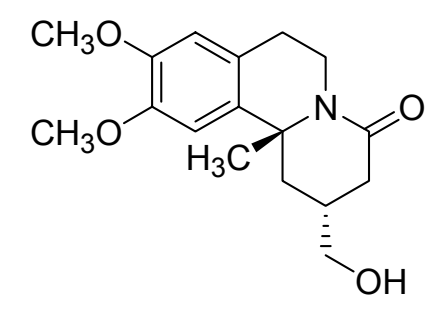

17

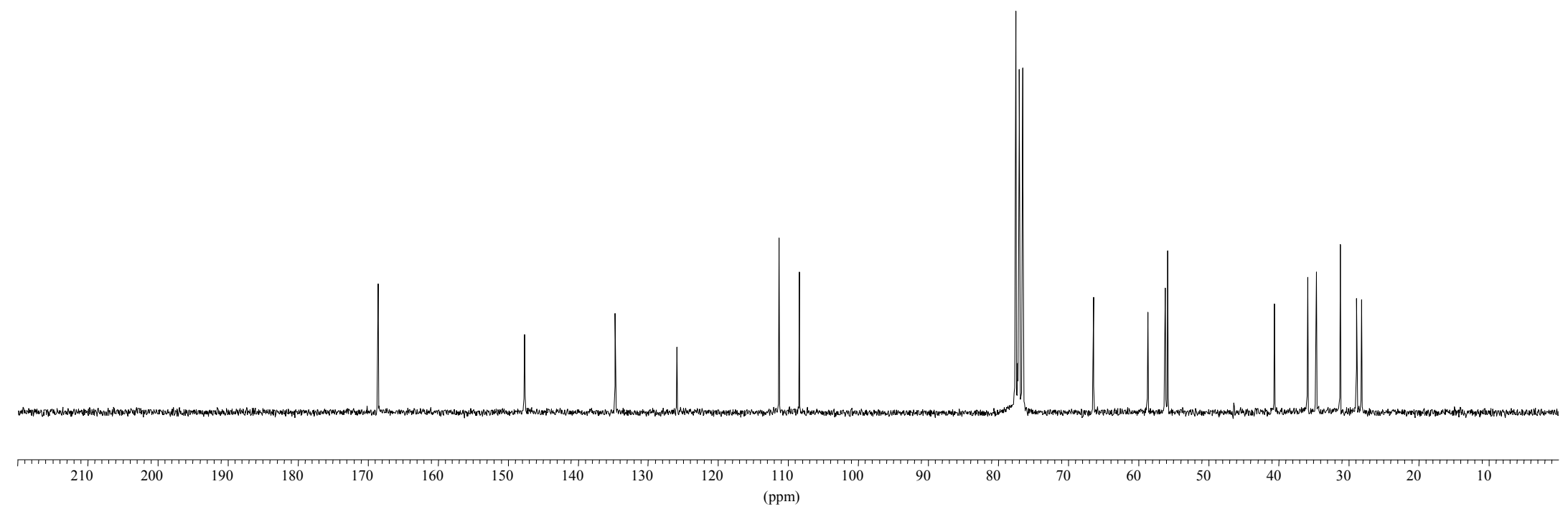




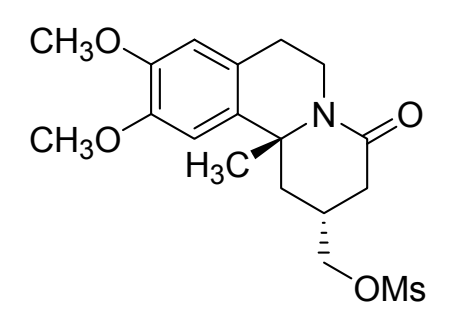

18

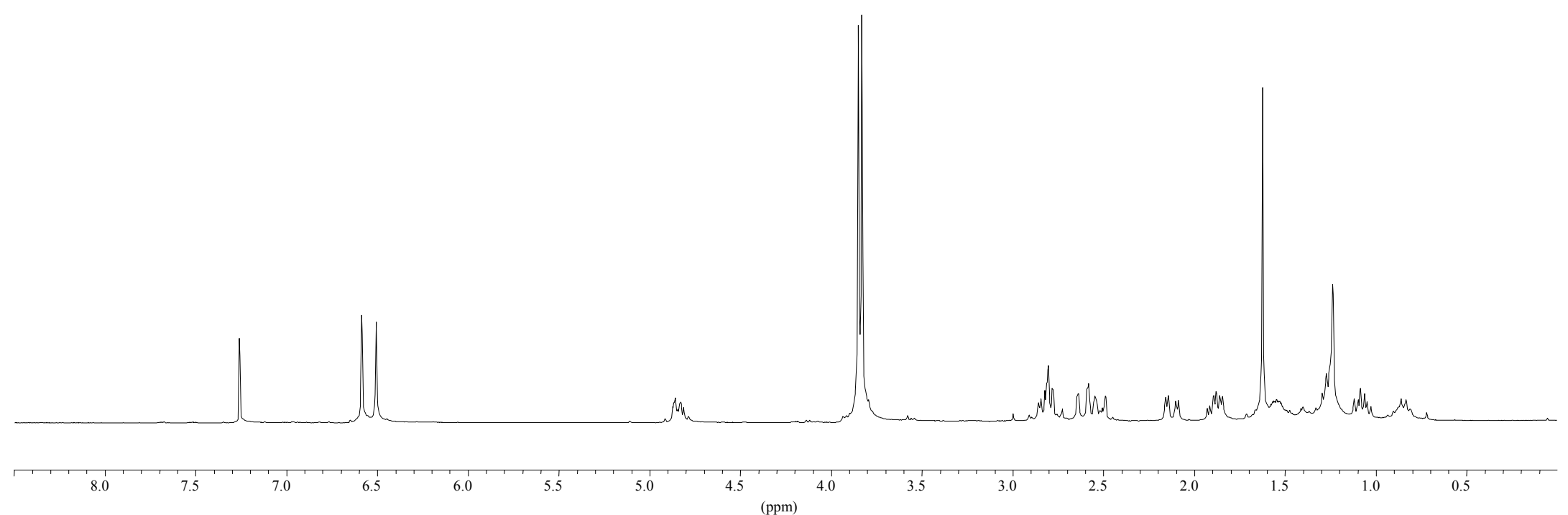




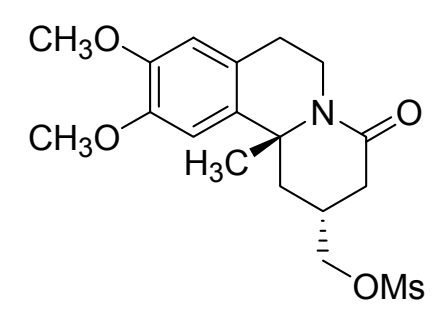

18

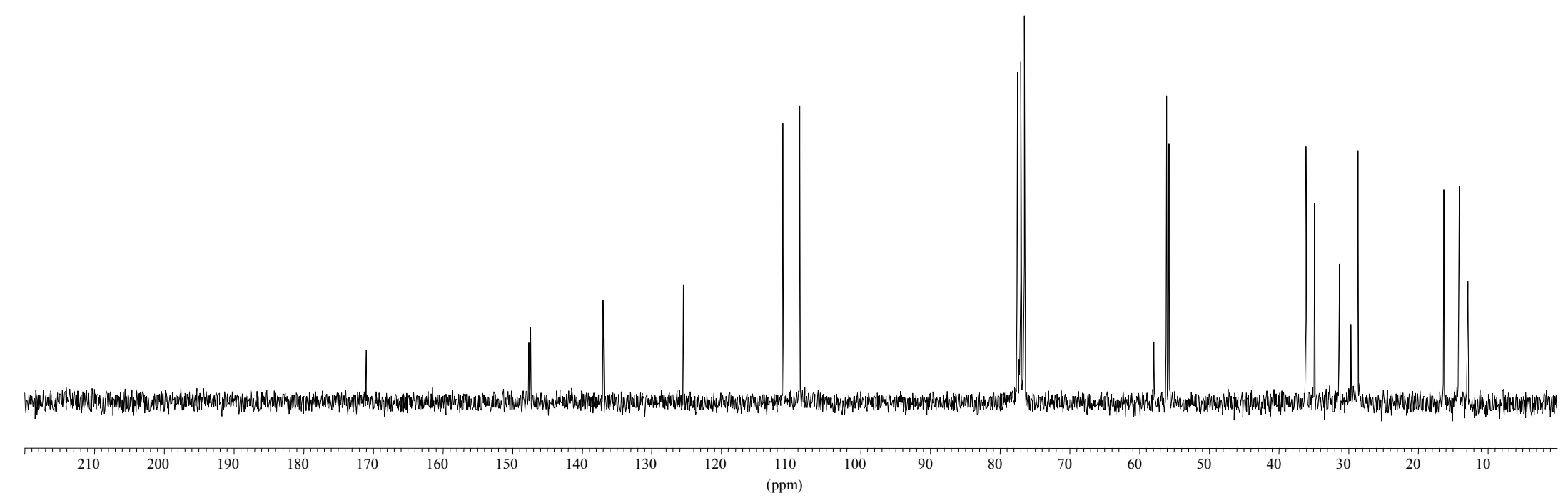




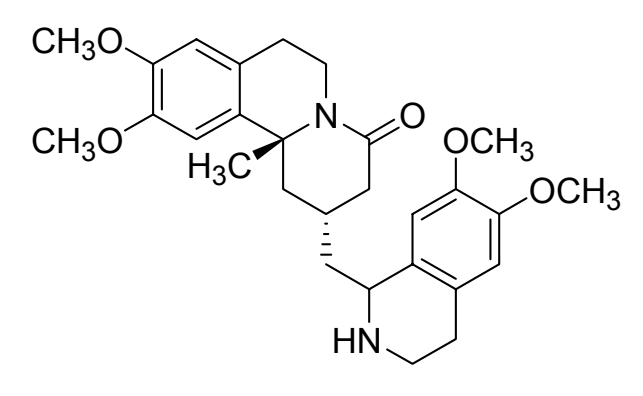

$21 \mathrm{dr}$ 1:1

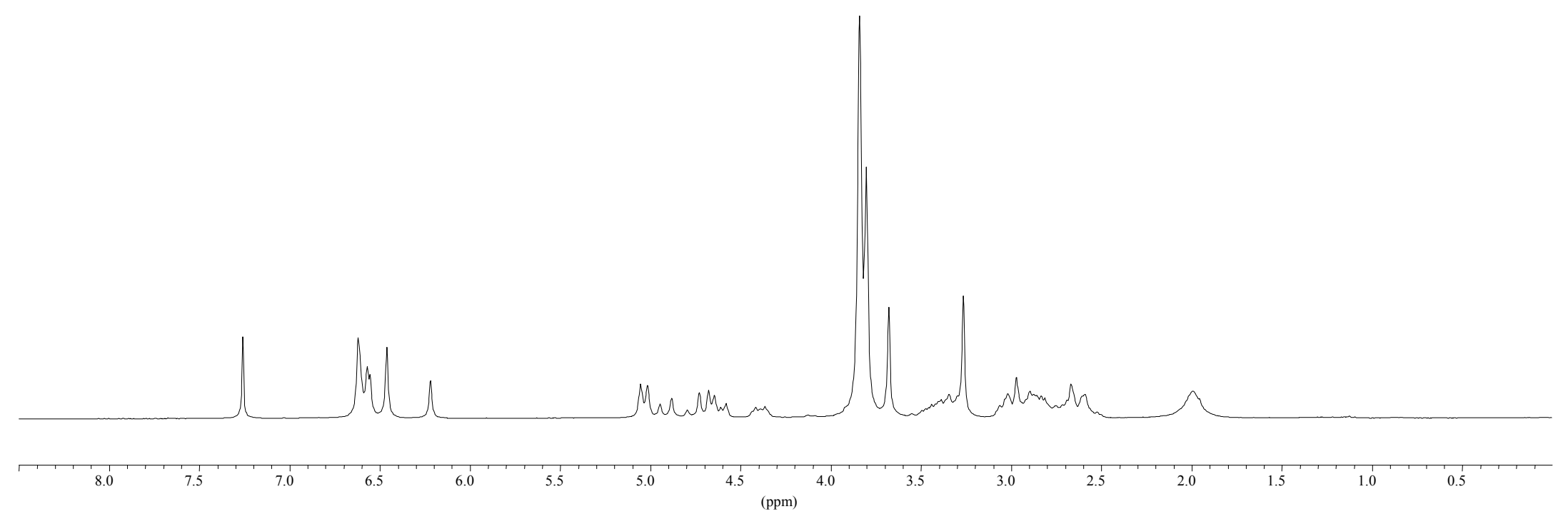




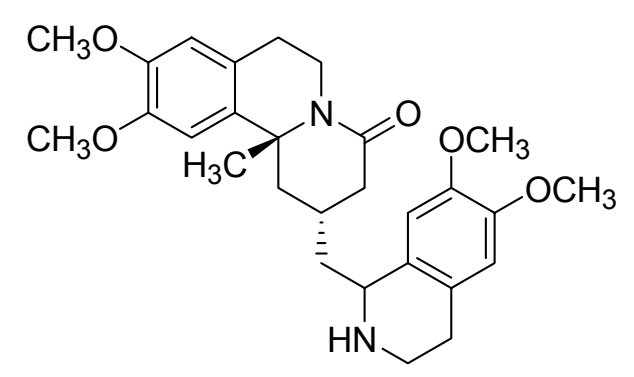

$21 \mathrm{dr}$ 1:1
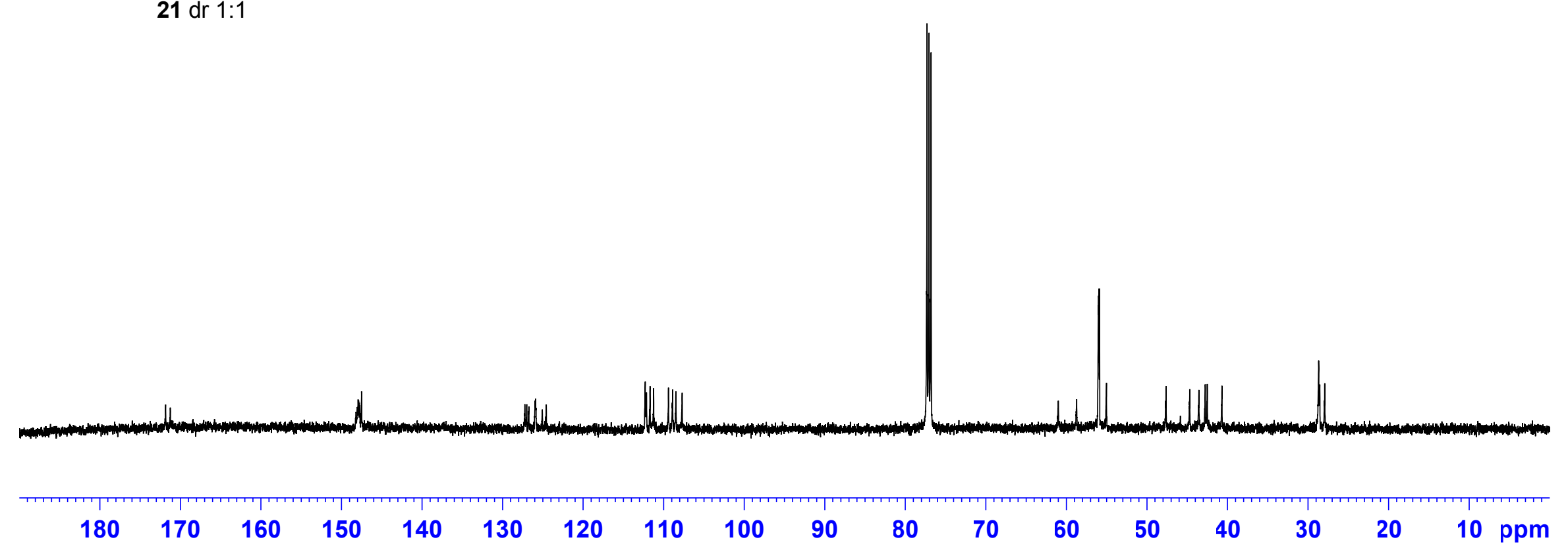


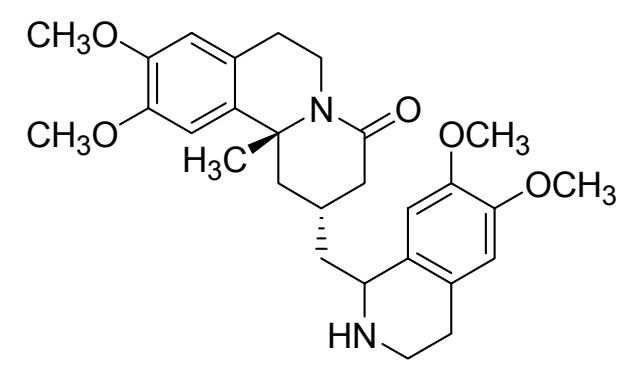

$21 \mathrm{dr}$ 1:1

COSY spectrum of $\mathbf{2 1}$

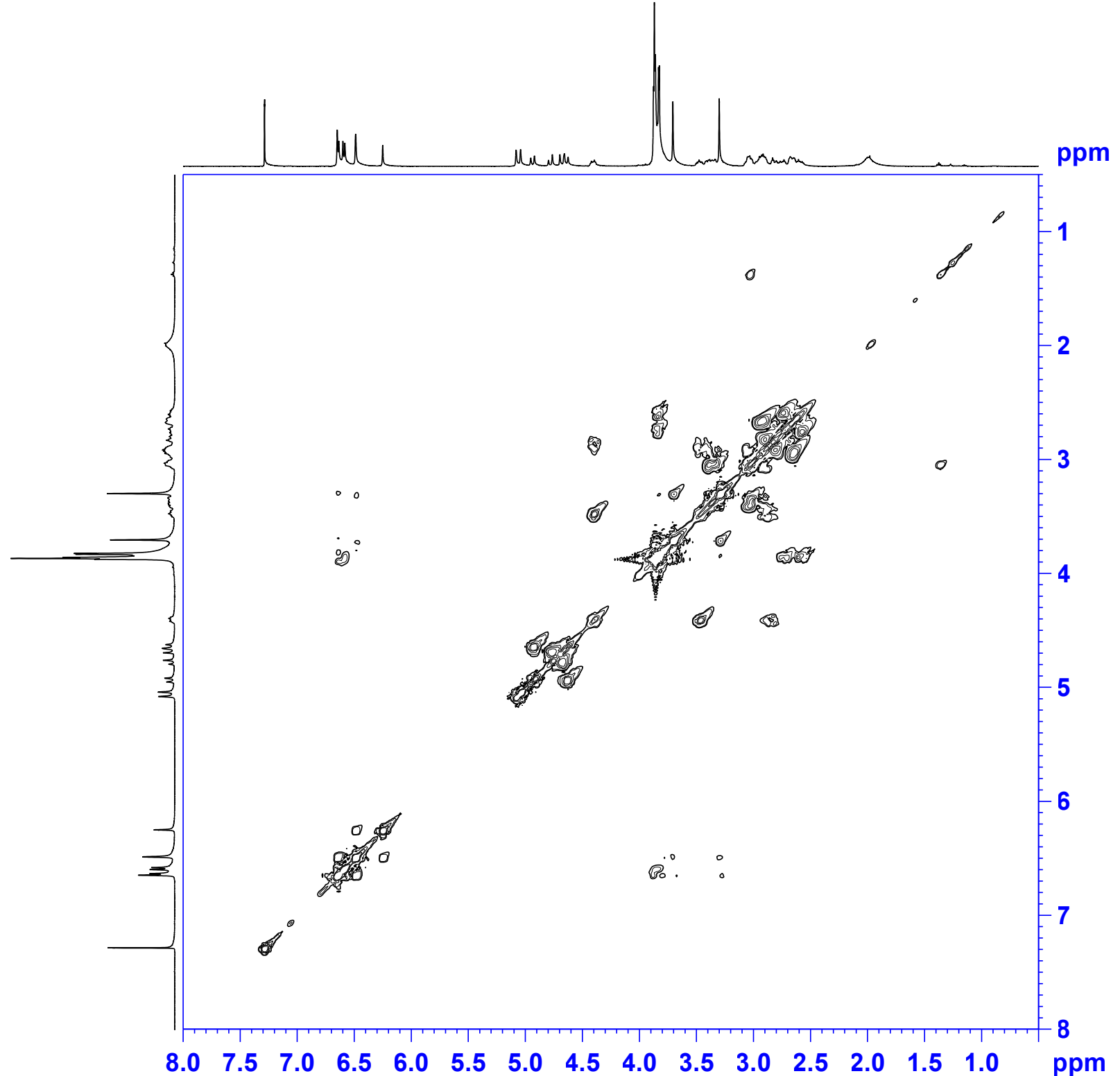

S-59 


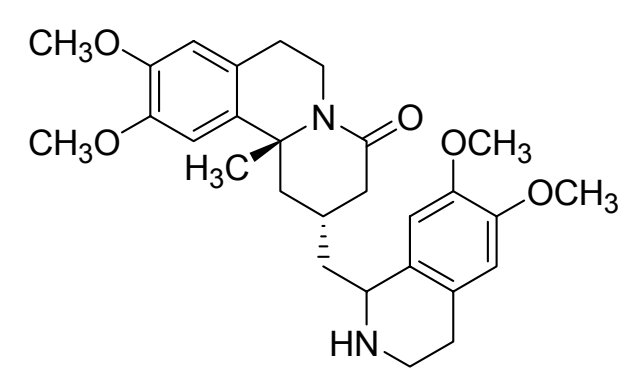

$21 \mathrm{dr}$ 1:1

HMQC spectrum of $\mathbf{2 1}$

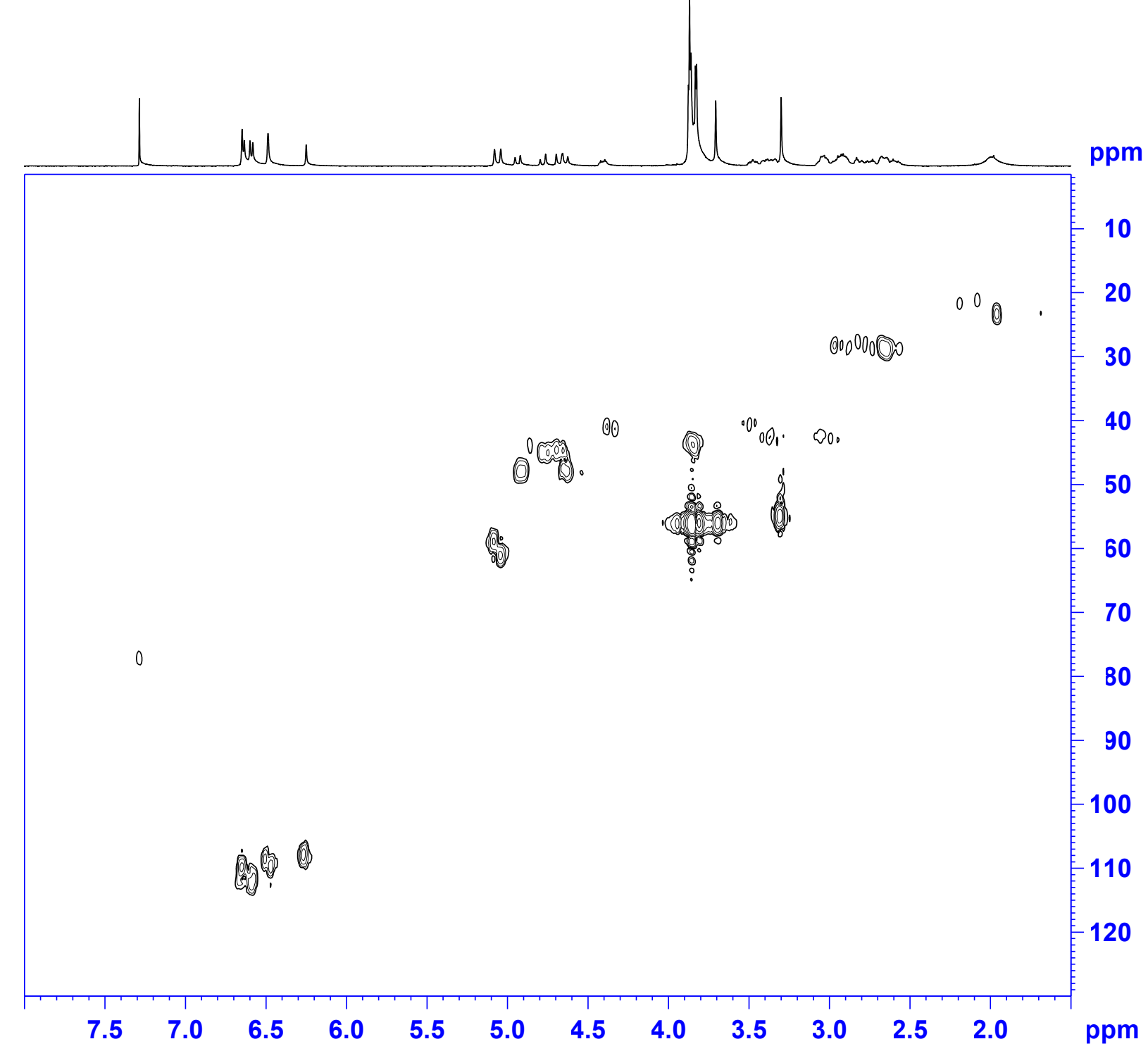

